\title{
Prevention of tumor risk associated with the reprogramming of human pluripotent stem cells
}

\author{
Kenly Wuputra ${ }^{1,2}$, Chia-Chen Ku, ${ }^{1,2}$, Deng-Chyang Wu ${ }^{2,3}$, Ying-Chu Lin ${ }^{4}$, Shigeo Saito ${ }^{5,6^{*}}$ and \\ Kazunari K. Yokoyama ${ }^{1,2,5^{*}}$ (D)
}

\begin{abstract}
Human pluripotent embryonic stem cells have two special features: self-renewal and pluripotency. It is important to understand the properties of pluripotent stem cells and reprogrammed stem cells. One of the major problems is the risk of reprogrammed stem cells developing into tumors. To understand the process of differentiation through which stem cells develop into cancer cells, investigators have attempted to identify the key factors that generate tumors in humans. The most effective method for the prevention of tumorigenesis is the exclusion of cancer cells during cell reprogramming. The risk of cancer formation is dependent on mutations of oncogenes and tumor suppressor genes during the conversion of stem cells to cancer cells and on the environmental effects of pluripotent stem cells. Dissecting the processes of epigenetic regulation and chromatin regulation may be helpful for achieving correct cell reprogramming without inducing tumor formation and for developing new drugs for cancer treatment. This review focuses on the risk of tumor formation by human pluripotent stem cells, and on the possible treatment options if it occurs. Potential new techniques that target epigenetic processes and chromatin regulation provide opportunities for human cancer modeling and clinical applications of regenerative medicine.
\end{abstract}

Keywords: Cancer risk, Cell reprogramming, Pluripotent stem cells, Regenerative medicine, Therapeutic agents

\section{Background}

The first successful mammalian reprogramming of vegetal cells to totipotent cells using the technology of nuclear transfer generated the cloned sheep "Dolly" [1]. In recent decades, the problems caused by tumorigenesis generated by oocytes (embryos) created by nuclear transfer have been underestimated. The creation of induced pluripotent stem cells (iPSCs) requires the expression of stemness-related genes, such as the combination of Oct4, Sox2, Klf4, and c-Myc (OSKM) and that of

\footnotetext{
* Correspondence: Saict1@maple.ocn.ne.jp; kazu@kmu.edu.tw

${ }^{5}$ Waseda University Research Institute for Science and Engineering, Shinjuku, Tokyo 162-8480, Japan

'Graduate Institute of Medicine, Kaohsiung Medical University, 100 Shih-Chuan 1st Rd., San-Ming District, Kaohsiung 807, Taiwan

Full list of author information is available at the end of the article
}

Oct4, Sox2, Nanog and Lin28 (OSNL) [2-5]. Studies of the risk of tumorigenesis and cancerous transformation have considered somatic cell reprogramming in the context of cancer patient-specific reprogramming [2-12].

Stem cells are putative candidates for cancerous transformation given their ability to self-renew and to dedifferentiate, which can lead to the acquisition of both the genetic and epigenetic modifications required for tumorigenesis $[13,14]$. The stemness-related transcription factors are expressed in embryonic stem cells (ESCs) and adult stem cells, but they are not generally expressed in adult somatic cells. Abnormal expression of ESC-specific factors has recently been reported in human tumors [15-17]. A retrospective study of human patient cohorts has shown that the expression of these factors with survival outcomes in specific tumor types, 
which suggests that these factors may be useful for assessing patient prognosis [18].

A recent study reported that the clinical expression of the pluripotent factors OCT4, SOX2, and NANOG $(\mathrm{OSN})$ in cancer patients was associated with treatment resistance of lethal cancers [19]. This expression signature was observed in a large cohort of cancers $(n=884)$, comprising renal $(n=317)$, bladder $(n=292)$, and prostate $(n=275)$ cancers. The rates of triple coexpression of OSN were 93,86 , and $54 \%$ in prostate, invasive cancer of bladder, and renal cancer, respectively. The high level of expression of OSN was also related to worse prognosis and shorter survival. The major regulators of stem cell pluripotency correlated well with poor survival and treatment resistance of cancer.

One study showed the production of induced transformed cancer stem cells (CSCs) from differentiated cells [20]. Another study showed that the reprogramming of cancer cells with abnormal or deleted p53 enhanced the generation of pluripotent CSCs and the frequency of tumorigenesis by these reprogrammed CSCs [21]. A reprogramming method has been applied to several types of tumor cells as a possible trial for suppressing tumorigenesis [22-24]. In these studies, some reprogramming factors were delivered to cancerous cells to generate induced pluripotent CSCs (iPCSCs). This method may provide a good model of tumorigenesis and may have therapeutic potential in the prevention of the initiation of carcinogenesis.

In addition to the use of genetic materials to generate pluripotent stem cells, small-molecule compounds that can promote cell reprogramming have also been used to obtain iPSCs. Small molecules that target molecules in signaling pathways, including the inhibition of histone deacetylase (HDAC), Wnt signaling, and transforming growth factor $\beta$ (TGF $\beta$ ) can regulate the expression of genes for pluripotent factors, whose expression can lead to the reprogramming of cells [25]. Various molecules that promote cell reprogramming can be used as substitutes for genetic materials. These include recombinant reprogramming factors (e.g., OSKM) modified by a polyarginine [26] and by small-molecule compounds [27-32]. However, the use of chemically defined small molecules alone has not yet generated human iPSCs (hiPSCs) [33]. Furthermore, it has not been clarified whether these small-moleculedriven iPSCs have a reduced risk of tumorigenesis after their therapeutic transfer [34].

In this review, we discuss the current understanding of the risk of tumor formation associated with the reprogramming of various human stem cell-like cells and summarize the possible solutions, such as using anticancer treatments and inhibitors to suppress tumorigenesis in iPSCs, CSCs, and their derivatives (Fig. 1). We have excluded a description of the effects of long noncoding RNAs and microRNAs (miRNAs) on reprogramming in detail from this review article $[35,36]$.

\section{Characteristics of stem cells and tumor cells}

ESCs are established from the inner cell mass (ICM) of blastocyst and can differentiate into all types of cells [15, 16]. The ability to produce teratomas in immune-deficient

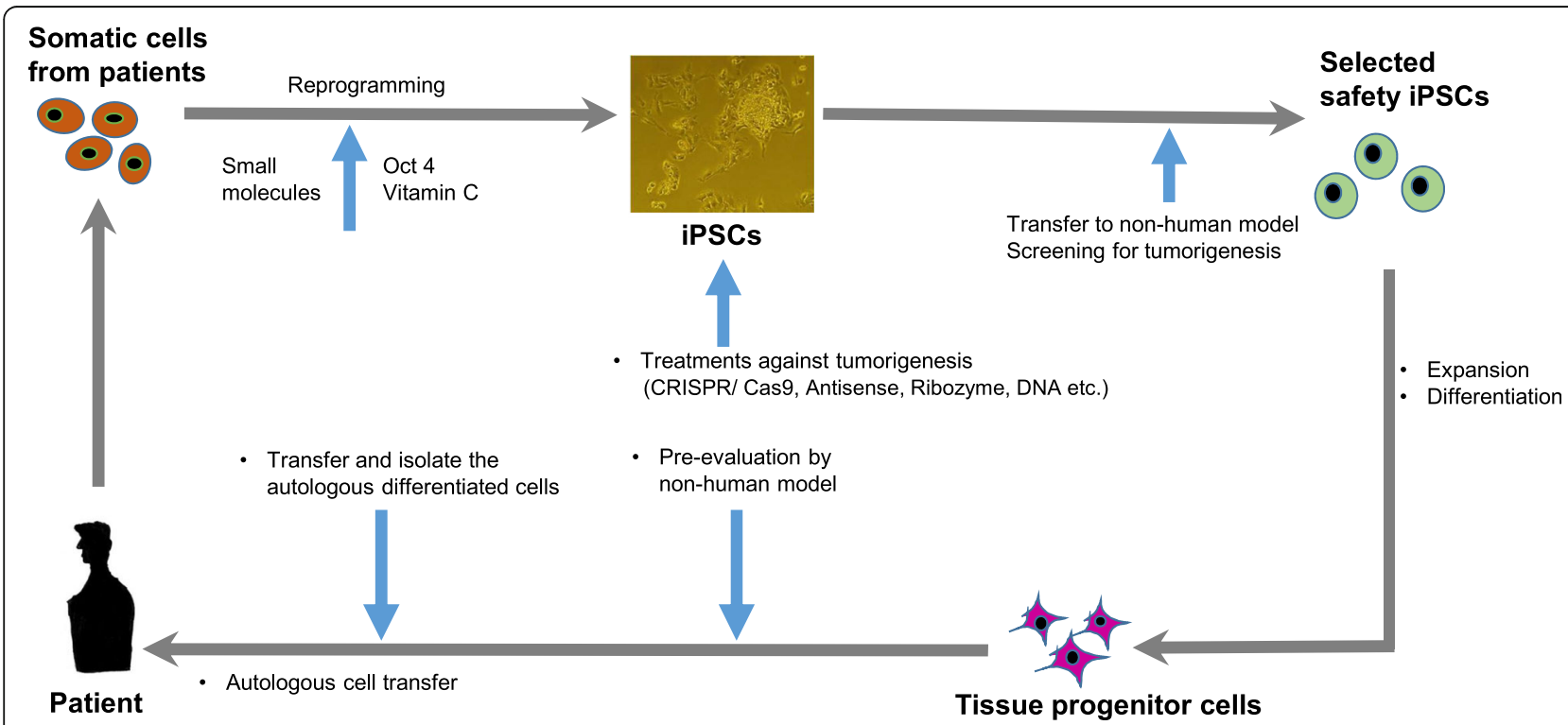

Fig. 1 Schematic representation of the recycling of autologous patient-specific induced pluripotent stem cells (iPSCs) to cure human diseases. Somatic cells from patients are established as patient-specific iPSCs, which are corrected genetically by repairing the defect and then differentiating the corrected iPSCs into autologous progenitor cells for use in transplantation. To correct a gene mutation in patient-specific iPSCS, the genetic code and epigenetic factors are corrected using gene editing, antisense, ribozymes, and peptide nucleic acid (PNA) or modified nucleic acids, and/or chromatin modification 
animals is common pluripotent properties of iPSCs and ESCs $[1,3$, 37]. Tumors comprise different types of cancer cells, and this contributes to the heterogeneity of tumors [20]. Teratomas are defined as mixed benign tumors that comprise abnormally developed tissues derived from germ cells with normal karyotypes [37]. Teratomas are regarded as posing no direct danger of forming a malignant tumor, although they have the potential to metastasize in response to some interactions with their microenvironment and niches [38]. Substantial number of tumors can be generated by a series of mutations, which can cause uncontrolled cell division. The process of tumorigenesis is specified by alterations in genetic, epigenetic, cellular, and microenvironmental circumstances [20]. Therefore, the risk of tumorigenesis by any stem cell-derived transplants needs to be eliminated before their clinical applications.

\section{Stemness-related transcription factors in stem cells and cancer cells}

To understand difference between and similarities in marker genes in CSCs and ESCs, we have summarized the corresponding signals and their characteristics (Table 1) $[16,17,39]$.

A few examples are described below.

\section{OCT4}

Expression of OCT4 is required for the maintenance of ESC characteristics [123]. Oct4-deficient mice do not generate the ICM and thus differentiate into the trophectoderm [123]. In addition, reduced expression of Oct4 in mouse ESC ( $\mathrm{mESC}$ ) caused in the upregulation of trophectoderm genes (e.g., $C d x 29$ ), whose overexpression leads to differentiation into the primitive endoderm and mesoderm [124]. Under serum-free culture conditions, the forced expression of Oct4 in ESCs promotes neuronal differentiation [125]. High expression level of OCT4 is related to poor prognosis in bladder cancer [126, 127], prostate cancer [128], medulloblastoma [129], esophageal squamous cell carcinoma [130], leukemia, and cancers of the ovaries, testicles, and pancreas [18].

\section{SOX2}

Expression of Sox 2 is detected in ICM and extraembryonic ectoderm of preimplantation blastocysts [131]. Sox2deficient blastocysts cannot generate a pluripotent ICM. Sox2-deficient mESCs differentiate into trophectoderm, and the overexpression of Oct4 can rescue the pluripotency of Sox2-deficient mESCs [132]. These findings suggest that Sox 2 is essential to maintain Oct4 expression. Moreover, the synergistic action of Sox 2 and Oct4 in OctSox stem cells-enhancers leads to the regulation of various pluripotent genes, including Oct4, Sox2, and Nanog. In contrast, forced expression of Sox 2 in ESCs is reported to lead to their differentiation [133, 134]. This effect was reflected by the reduced expression of pluripotency genes Sox2, Oct4, Nanog, Fgf4, and Utf1 [133] and the induced generation of neuroectoderm, mesoderm and trophectoderm [134]. Increased expression of SOX2 correlates with poor prognosis in stage I lung adenocarcinoma [135], esophageal squamous cell carcinoma [136, 137], gastric carcinoma [138-140], small-cell lung carcinoma [141143], breast cancer [144], testicular tumors [145], and ovarian carcinoma [146].

\section{KLF4}

KLF4 is one of the Krüppel-like transcription factors family that are involved in reprogramming. Klf4 is expressed in $\mathrm{mESCs}$ and is repressed during differentiation [147]. The RNA interference against Klf4 led to the differentiation of ESCs [148, 149], whereas the forced expression of KLF4 delays the differentiation, increases the expression of OCT4, and stimulates self-renewal ability [150]. Klf4 with Oct4 and Sox2 induces the expression of Lefty1 [151] and Nanog [152], KLF4 is also a prognostic predictor of colon cancer [153] and head neck squamous cell carcinoma [154], and is also detected in leukemia, myeloma, testis cancer [18], early stage breast cancer [155], nasopharyngeal cancer [156], and oral cancer [157].

\section{Nanog}

In the absence of the leukemia inhibitor factor-signal transducer and activator of transcription (LIF-STAT3) pathway, Nanog is required for the maintenance of ESC properties $[158,159]$. Chamber et al. found that expression of Nanog was high in Oct4-knockout embryos, whereas its overexpression did not counteract the differentiation program of ESCs induced by Oct4 deletion [159]. In the absence of Nanog, embryos did not produce a pluripotent ICM, but Nanog deficient mESCs could be established $[158,160]$. Nanog downregulation in human ESCs promotes differentiation toward the extraembryonic lineage, as demonstrated by the forced expression of endodermal and trophectodermal specific genes. OCT4-SOX2 heterodimer complex binds to the Octamer-Sox cis-elements in the proximal promoter of NANOG gene and regulate NANOG expression in ESCs [161]. Moreover, Nanog, Oct4, and Sox 2 cooperate with the signaling pathway mediators, which means that signals are delivered directly to the genes regulated by the core factors [162]. Higher expression of NANOG is concerned with poor prognosis for testicular cancer [163], colorectal cancer [164], gastric cancer [140], non-small cell lung carcinoma $[165,166]$, ovarian cancer [167], and liver cancer [168].

\section{C-Myc}

c-Myc is one of the factors for stem cell pluripotency, proliferation, and apoptosis [169-171]. c-Myc is directly 


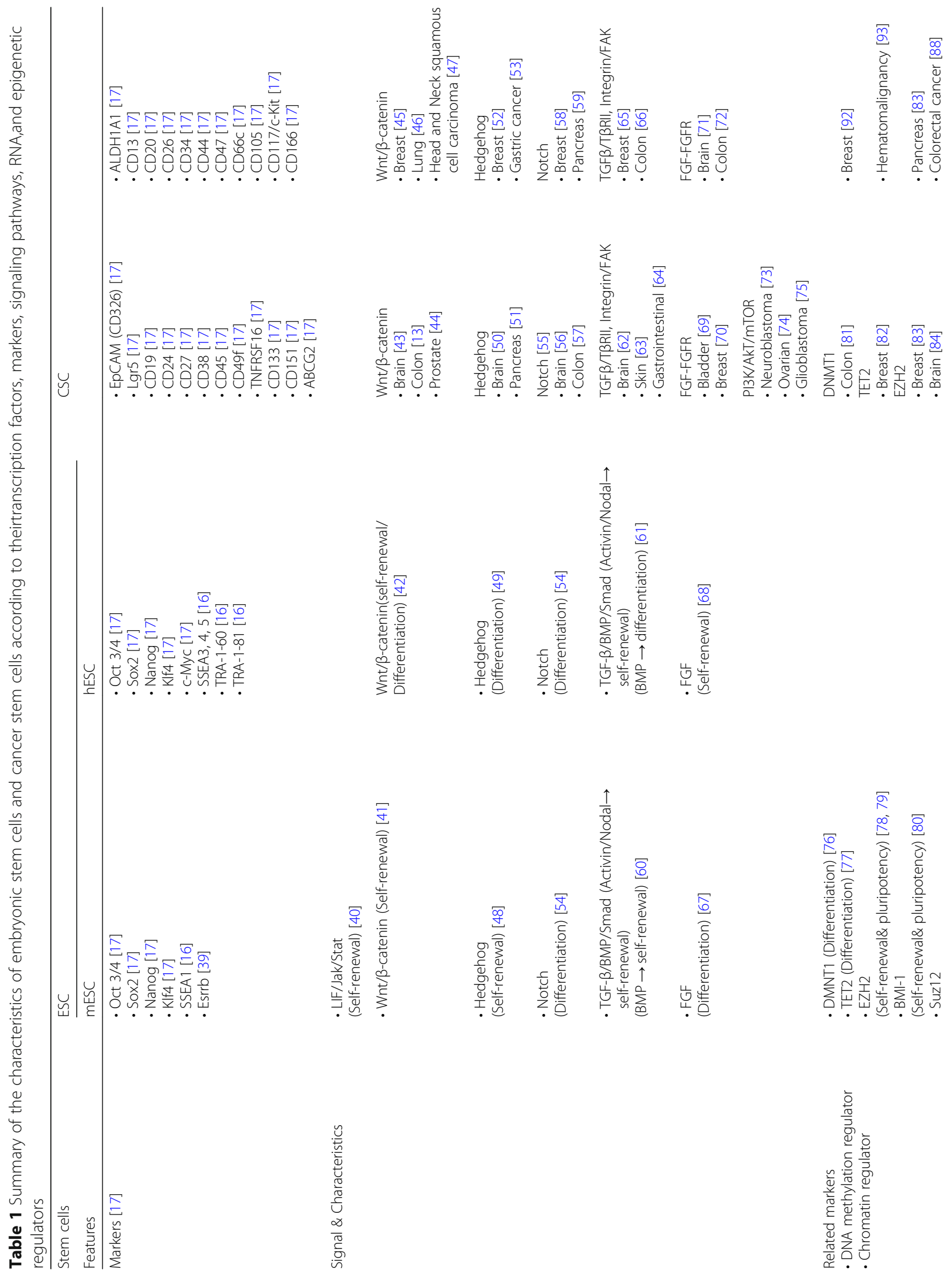




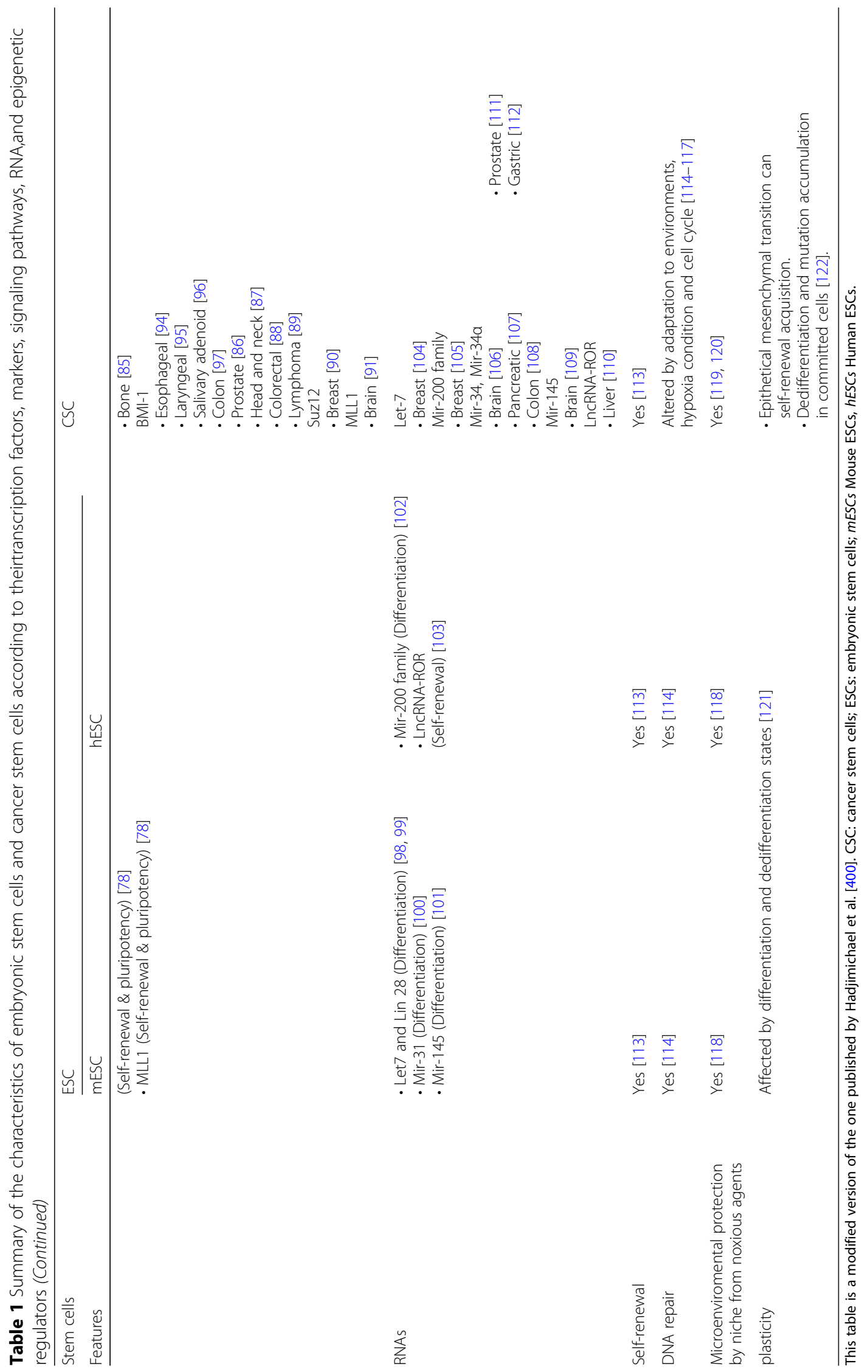


regulated by LIF-STAT3 signaling, and its constitutive expression renders ESC self-renewal independent of LIF. However, the forced expression of dominant-negative cMyc induces differentiation [172]. It has been reported that c-Myc represses signaling of the mitogen-activated protein kinase (MAPK) pathway, which led to the inhibition of differentiation [173]. c-Myc binds and regulates the transcription of at least 8000 genes in ESCs including those for E2F-Max complexes, and NuA4 HAT complex, which regulate ESC pluripotency [174]. c-Myc was one of the most important leukemia stemness factors. C-MYC overexpression is found in over $70 \%$ of human cancers, including breast cancer, colon cancer, glioma, medulloblastoma, pancreatic cancer, and prostate cancer [18, 175]. c-MYC expression correlates with poor prognosis for hepatocellular carcinoma [176] and early carcinoma of the uterine cervix $[177,178]$. c-MYCdriven reprogramming is controlled by the activation of c-MYC-mediated oncogenic enhancers in human mammary epithelial cells [179].

\section{p53}

The inhibition of the tumor suppressor protein 53 (TP53) increases the rate of reprogramming of fibroblasts to iPSCs [180, 181], which can differentiate into dopaminergic neurons directly from human fibroblasts [182].

\section{$J D P 2$}

The c-Jun dimerization protein 2 (JDP2) is a member of the AP-1/ATF family of transcription factors and can function as a histone chaperone that regulates transcription [183-185]. JDP2 is a reprogramming factor because it can regulate the Wnt signaling and function as a suppressor of producing reactive oxygen species (ROS) [186-189]. For example, addition of the ROS scavenger vitamin $C$ to the culture medium significantly increases the reprogramming efficiency of cultured cells [190]. Activation of the Wnt signaling can maintain the ability for pluripotency in ESCs [41, 191-194]. ESCs can differentiate into all types of cells, except for some in extraembryonic tissues [37, 38]. The cell reprogramming method that uses OCT4 and JDP2 to generate gastric cancer cells is based on this notion [195]. In that study, reprogramming using these two factors inhibited the tumorigenic function of gastric cancer cells by inhibiting bone morphogenetic protein 7 (BMP7). Moreover, reprogrammed gastric CSC-like cells induced a lower level of tumor formation in immune-deficient mice than did the parental cancer cells [195]. This method is a good example of a therapeutic strategy that might restrict cancer progression by using JDP2 together with OCT4 as reprogramming factors. Collectively, accumulating evidence suggests that ESCs and CSCs share major transcription factors.

\section{Surface markers for stemness in CSCs}

The uncontrolled proliferation of many tumors is driven by a small population of cancer cells, known as CSCs, which exhibit the capacity for self-renewal and pluripotency. Unlike somatic cancer cells, CSCs can produce an obvious cancer and propagate the malignant cancerous clones indefinitely. Like the stemness-related transcription factors, surface markers that are expressed in stem cells are also expressed in human cancers. These include TRA-1-60, Stage specific embryonic antigen-1(SSEA-1), Epithelial cell adhesion molecule (EpCAM), Aldehyde dehydrogenase 1 family, member A1 (ALDH1A1), Leucinerich repeat-containing G-protein coupled receptor 5 (Lgr5), CD13, CD19, CD20, CD24, CD27, CD34, CD44, CD45, CD47, CD49f, CD66c, CD90, CD166, TNFRSF16, CD105, CD133, c-Kit, CD138, CD151, and CD166. Table 1 shows the surface markers of CSCs, some of which are targets of therapeutics in cancer treatment.

\section{CD133}

CD133 is a transmembrane glycoprotein that localizes to cellular protrusions. It is originally known as a stem cell marker which is detected in neuroepithelial stem cells [196] and has been recognized as a CSC marker [197]. This molecule is used to identify many different types of CSCs, including those originating from glioma [198], and colorectal [199, 200], lung [201], liver [202], and prostate [203] cancers. CD133 has been shown to be involved in the regulation of glucose uptake and glucosamine production under condition of high-glucose, circumstances related to glycolysis, and autophagy [204]. However, knockdown of CD133 has no significant effect on cancer development [205]. Both CD133+ and CD133- metastatic colon cancer cells are initiated equally during the early stage of tumor formation [206], which indicates that CD133 expression is not specific and not restricted to stem cells. Therefore, CD133 seems to reflect glucose availability and is not a specific marker of CSCs.

\section{CD44}

CD44 is another transmembrane glycoprotein. CD44 is concerned with cell division, migration, and adhesion via different signaling [207]. It is expressed in both normal fetal and adult hematopoietic stem cells. Upon binding to hyaluronic acid (HA), its primary ligand, CD44 mediates cell-cell communication and signal transaction. HA binding to $\mathrm{CD} 44$ on cell surface molecules, such as selectin, collagen, osteopontin, fibronectin, and laminin, activates the epidermal growth factor receptor tyrosine kinase and increases cell proliferation and survival through the signals of MAPK and phosphatidylinositol3-kinase (PI3K)-Akt pathways [208, 209]. Knockdown of $\mathrm{CD} 44$ prevents the tumors occurrence induced by colorectal CSCs [205]. CD44 plays a role in in the invasive 
and tumorigenic abilities with stemness features of several tumor cell types, including breast [210, 211], prostate [212, 213], colon [214, 215], and pancreas [216] cancers, and head and neck squamous carcinoma [217]. Therefore, CD44 is not specific for CSCs but is more of a marker of invasive or metastatic cells. Several other CSC surface markers appear to function in specific types of tumors.

\section{ABCG2}

ABCG2 is one of the ATP-binding cassette transporter $(\mathrm{ABC})$ family. ABCG2 may be a universal biomarker of stem cells [16]. ABCG2 plays a vital role in stimulating the proliferation of stem cells and, in the case of esophageal squamous carcinoma, has been shown to be required for the maintenance of the stem cell phenotype [218]. The sensitivity of hepatocarcinoma cells to the chemotherapeutic drugs, doxorubicin and 5-fluorouracil, correlates inversely with the surface levels of AGCG2. The AGCG2 level expressed on cancer cells, including colon cancer lines, also correlates closely with tumorigenicity, drug resistance, proliferation, and metastatic ability $[219,220]$.

\section{CD13}

CD13 encodes the enzyme aminopeptidase N, a Zn2 + -dependent membrane-bound ectopeptidase. CD13 is overexpressed in multiple cancers, including hepatocarcinoma [221], and colon cancer [222], as well as on the surface of vasculature endothelial cells in tumors undergoing angiogenesis [223].

\section{Lgr5}

Lgr5 is one of the leucine-rich repeat-containing Gprotein-coupled receptor (GPR49) family, which belongs to the seven-transmembrane G-protein-coupled receptor super family. Lgr1 $\sim 5$ family members are regulatory receptors involved in Wnt signaling [224]. Lgr5 binds to the furin-like repeat domains of R-spondin $1 \sim 4$ (RSPO1 $\sim$ ) to potentiate WNT signaling [225]. However, RSPO1-Lgr5 can also directly activate TGF $\beta$ signaling in a cooperative interaction with the TGF $\beta$ type II receptor on colon cancer cells, which increases growth inhibition and apoptosis [226]. The effect of Lgr5 expression depends on its interactions with the both Wnt and TGF $\beta$ signaling systems [227]. Lgr5 is expressed in many organs including the brain, mammary glands, intestinal tract, stomach, hair follicles, eyes, and reproductive organs [226]. Lgr5 is also a Wnt signaling target. Its expression I increased in prostaglandin E2 (PGE2)treated colorectal cancer cell lines, but Lgr5 knockdown inhibits the PGE2 survival response and increases cell death [224]. Lgr5 seems to be a global marker of adult stem cells, such as those found in the hair follicles, intestine, liver, colon, rectum, and ovaries [228], and a definitive surface marker of colorectal CSCs that is coexpressed with CD44 and EpCAM [229].

\section{CD326 (EpCAM)}

The surface marker EpCAM is a type I transmembrane glycoprotein that acts as a calcium-independent homophilic adhesion receptor with a molecular weight 30-40 $\mathrm{kDa}$. EpCAM is expressed in epithelial tissues, progenitor cells, cancer cells, and stem and germ cells [230]. EpCAM can be downregulated when cancer cells undergo the epithelial-mesenchymal transition (EMT). The wide distribution of EpCAM expression on most cancer cells indicates that it is not a specific marker of CSCs [231].

\section{Stemness-related signaling pathways}

Three processes such as maintenance, self-renewal, and differentiation are concerned with embryonic development and homeostasis of adult tissues. Cancers commonly exhibit aberrant functions within these pathways, often in a cell context-dependent manner. Here we discuss the current evidence for the control of the Hedghog (Hh), Notch, LIF-JAK-STAT, PI3K-Akt-mammalian target of rapamycin (mTOR) and Wnt/ $\beta$-Catenin pathways in CSCs.

\section{Hh signaling}

The Hh ligands (Desert hedgehog, Sonic hedgehog, and Indian hedgehog) bind to Patched, which activates downstream signals that lead to the nuclear localization of transcription factors, followed by the upregulation of genes involved in survival, proliferation, and angiogenesis [232]. Hh is the major regulator of vertebrate embryo development, stem cell maintenance, cell growth and differentiation, tissue polarity, cell proliferation, and the EMT [233]. Hh signaling is implicated in CSC selfrenewal and cell-fate determination [232] and is considered as a potential therapeutic target in the treatment of breast cancer and pancreatic cancers [234].

\section{Notch signaling}

Notch is controlled with cell-cell communication through transmembrane receptors and ligands. In human ESCs, Notch signaling governs the cell-fate determination in the developing embryos and is required for the development of all three germ layers from undifferentiated ESCs [235]. In CSCs, Notch controls tumor immunity and CSC maintenance [59]. Notch signaling is frequently dysregulated in cancers, which provides a survival advantage for tumors and a potential target in the treatment of cancers [236]. 


\section{LIF-JAK-STAT signaling}

LIF-JAK-STAT signaling governs the cell-fate determination, is important in cytokine-mediated immune responses, and is involved in many biological processes such as proliferation, apoptosis, migration, and stem cell regulation [237]. Tight control of JAK-STAT signaling is required for maintenance of stem cells, self-renewal, and anchoring of stem cells in their respective niches by through the regulation of different adhesion molecules.

\section{PI3K-Akt-mTOR signaling}

PI3K-Akt-mTOR signaling is crucial to stem cell proliferation, metabolism, and differentiation. This pathway may dysregulate in human cancers [238]. Over $70 \%$ of ovarian cancer cells is reported to activate PI3K-AktmTOR pathway. This pathway is a therapeutic target in the treatment of this cancer type [74] as well as for neuroblastoma [239], endometrial cancer [239], and acute myeloid leukemia [240].

\section{Wnt- Bcatenin signaling}

Wnt signaling plays a role in the stem cell differentiation, and dysregulation of Wnt signaling is associated with the expansion of stem and/or progenitor cells, as well as carcinogenesis [241], Targeting of Wnt is one treatment option for hematological malignancies [242], liver cancer [243], and other types of tumors [244].

\section{Mutation of the genome}

The first event that triggers the transformation of normal cells into abnormal cells is mutation of the genome. Such mutations may be maintained, and other events, such as changes in the epigenome of stemness-related genes, oncogenes, and tumor suppressor genes, can also trigger the transformation into abnormal cells.

In general, "driver" mutations occur during the initiation stage of cancer and are followed by the accumulation of "passenger" mutations and tumorigenesis [245, 246]. Driver mutations trigger the growth and development of cancers, whereas passenger mutations do not affect clonality [247-249]. Recent progress in the technology of deep sequencing has led to identify these mutations in particular oncogenes and/or tumor suppressor genes [250]. However, whether these mutations can become a barrier to the reprogramming of cancer cells remains unclear. Moreover, the reprogramming of cancer cells may induce genomic changes, including chromosomal aberrations, copy number variations (CNVs), and single-nucleotide variations. For example, chromosome abbreviations at trisomy 12, chromosome 8, and chromosome $\mathrm{X}$ have been found in ESCs and iPSCs [251-256]. CNVs have been detected during reprogramming or mosaicism from parental cells. In some cases, CNVs are also lost by passaging of cells [254, 257-260].
Single-nucleotide mutations have been analyzed using high-throughput next-generation sequencing technologies [261, 262]. Additional investigation is required to characterize the occurrence of these mutations during cell reprogramming. Mutations in mitochondrial DNA in human iPSCs increase with age, and the use of young donor cells may be one option to overcome this problem $[263,264]$.

\section{Epigenetic alterations}

The oncogenic potential of reprogrammed stem cells correlates with epigenetic and genomic instability [265, 266]. Epigenetic instability during cancer progression can lead to commitment to altered gene expression. Tumor generation can be caused by epigenetic reprogramming such as carcinogenic enhancer reactivation in both somatic and cancer cells [267-269]. In general, DNA methylation can silence the expression of the tumor suppressor genes that are required for sustaining normal function, whereas aberrant expression of oncogenes can lead to cancer initiation [270-272]. Intriguingly, iPSCs generated from human sarcoma cell lines have the same methylation and demethylation status in the promoters of oncogenes and tumor suppressor genes in the initial stages. In some cases, iPSCs can suppress the oncogenic promoters and maintain the activity of the promoter of tumor suppressor genes. These finding suggest that stem cell factors can inhibit the expression of cancer phenotypes, perturb epigenetics, and change cancer-related gene expression [266].

The factors that regulate chromatin are another possible target for circumventing the cancer risk during cellular reprogramming. Histone modification, noncoding RNA alteration, and chromatin alteration around mutated regions of DNA are key events that change oncogenic features [273]. Moreover, recent evidence of super-enhancers, locus control regions, and phase separation has provided new targets for next-generation reprogramming, to limit the oncogenic risk associated with cell reprogramming [273-275]. The methodologies chosen to induce these epigenetic and chromatin changes require careful consideration.

\section{Epigenetic modifiers and cancer cell plasticity}

The differences between CSCs and adult stem cells in the early stage are reflected in differences in stemness signals, such as BMP, notch receptor 1 (Notch 1), sonic hedgehog (Shh) signaling molecule, TGF $\beta$, and the wingless-type MMTV integration site family (Wnt). Later, EMT factors such as HIFs, the zinc-finger protein SNAI2 (Slug), the zinc finger protein SNAI1 (Snail), the class A basic helix-loop-helix protein 38 (Twist 1), and the zinc-finger E-box-binding homeobox 1/2 (Zeb 1/2) are activated, which leads to changes in epigenetic 
signatures during progression. Changes in the epigenetic machinery might be crucial for the acquisition of stemness characteristics by, and the tumorigenesis of CSCs [276].

The epigenetic barriers that determine cell plasticity must be overcome during the initial steps of cell reprogramming. In the first step, DNA methylation by DNA methyltransferases (DNMTs) occurs at CpG islands and is reversed by ten-eleven translocation proteins (TETs), followed by transcriptional silencing. Both DNMTs and TETs affect transcriptional initiation, elongation, splicing, and stability at the CpG-poor and repeat-rich intergenic loci of target genes [277]. Some methylated DNA-specific binding proteins also perform similar functions. In the second step, histone modifications, such as methylation, acetylation, ubiquitination, phosphorylation, and SUMOylation, cause changes in nucleosomes. These changes define functional regions such as promoters, enhancers, and insulators, which determine the transcriptional patterns and cell fates. In the third step, histone modifiers are used to control chromatin during transcription, replication, and genome maintenance.

Several histone modifiers can regulate transcription, such as the polycomb repressive complex (PRC) 1 and 2, and the enhancer of zeste homolog 2 (EZH2), which is the catalytic subunit of $\mathrm{PRC} 2$ that mediates transcriptional repression by introducing H3K27me3 [278]. By contrast, in glioblastomas, the H3K27M mutation in H3.1 and H3.3 leads to reduced EZH2 activity and a decreased level of H3K27me3, followed by a more primitive stem-like state $[279,280]$. Loss of EZH2 function can induce a transcription program for self-renewal and leukemogenesis [281]. Therefore, EZH2 mutation and deregulation of H3K27me3 seem to be linked.

The trithorax group (TrxG) complex is another factor that plays a role in the control of histone methyltransferase (HMT) in mixed-lineage leukemia (MLL) [282]. In this type of leukemia, the MLL fusion protein MLL-AF9, which lacks the catalytic domain, is produced by chromosomal rearrangement. The committed cells can be reprogrammed toward leukemic stem cells and initiate tumorigenesis [283]. MLL oncogenic fusion proteins require the repressive activity of $\mathrm{PRC} 1$, which monoubiquitinates histone H2A at lysine 119 (H2AK119Ubi) and mediates transcriptional repression in association with PRC2 [283]. BMI-1 in PRC1 is required to abolish tumor suppressor functions and to enhance CSC selfrenewal in solid tumors [284]. Finally, ATP-dependent chromatin modeling complexes that move, eject, or restructure chromatin, are also key elements in the control of tumorigenesis.

Four subfamilies are involved in chromatin remodeling in tumor cells, such as switch/sucrose nonfermentable (SWI/SNF), imitation switch, chromodomain helicase DNA binding protein 1, and INO80 complex ATPase subunit. These differ in their functions, protein domains, and subunit constituents [285]. Loss of SWI/SNF-related matrix-associated actin-dependent regulator of chromatin subfamily B member 1 , a subunit component of the SWI/SNF complex, results in genetic changes that drive rhabdoid tumors and are associated with the inhibition of differentiation, which leads to reprogramming toward oncogenic transcription for oncogenic signaling [286, 287]. The AT-rich interactive domain-containing protein $1 \mathrm{~A}$, another subunit of the SWI/SNF complex, functions as a tumor suppressor in colon cancers, and its deletion causes activation of the oncogenic transcriptional program for the promotion of invasive colon adenocarcinoma [288]. These data indicate that epigenetic modifiers also play a critical role in determining stemness/pluripotency and tumorigenesis.

Reversible epigenetic changes play a critical role in the fate decision in cancer cells, which can favor or disfavor the stem cell program that sustains tumor progression. Similarly, cell reprogramming involving epigenesis in cancer cells can generate iPSCs. Chromatin regulators such as the complex of PGC and TrxG proteins can regulate cancers and reprogramming [289]. In glioblastomas, several PRC and TrxG components play important roles in CSC development and in the plasticity of cancer cells. In adult glioblastoma, overexpressed MLL5 represses the expression of H3.3 in CSCs, which causes local reorganization of chromosomes [290]. The upregulation of MLL5 in non-stem cancer cells induces cell plasticity by inhibiting pro-neural differentiation, thereby eliciting a stem cell-like stage.

Another chromatin modifier, the linker histone variant H1.0, is also critical for the plasticity of cancer cells. Perturbation of H1.0 levels affects self-renewal activity directly and promotes the differentiation of non-stem cancer cells, thus blocking their tumorigenicity in vivo [291]. The plasticity of CSCs can be counteracted by epigenetic barriers that prevent cell reprogramming in vitro, such as the deposition of Suv39h1-associated H3K9me2/3 modifications [292]. An interesting insight into these epigenetic barriers was provided by a comparison of the epigenetics of gene expression between adult cells and CSCs in response to tissue damage [293]. In that report, tissue damage activated the resident stem cells, and CSCs exhibited overactivated stress-dependent enhancers and epigenetic modifications, which altered their cell fate and plasticity. These findings highlight the critical role of the reversibility of changes in the chromatin structure in the determination of the functional properties of CSCs.

\section{Alteration in the microenvironment during tumorigenesis}

The tumor microenvironment favors a stress-responsive enhancer, which may induce CSC plasticity. Therefore, the microenvironment and niche seem to be critical for 
the reprogramming to CSCs and iPSCs. Inflammation is an immune reaction to a pathogen [294], during which the responses of immune cells can lead to oxidative damage of DNA in infected cells. Nuclear factor $k B$ and STAT3 can cause parenchymal cells to produce excess amounts of ROS and reactive nitrogen species, which can induce genomic instability and DNA mutations [295]. Mutations and chromosomal alterations are thought to be associated with tumor progression, which may be potentiated by a chronic inflammatory microenvironment that are damaged by mutations.

During CSCs have developed, CSCs may create their own niche. Cells forming the CSC niche necessary for both the maintenance of CSCs and the generation of factors and tumor-associated cells that maintain CSC properties such as invasion, metastasis, and promotion of angiogenesis [296]. The CSCs niche contains cellular components such as cancer-associated fibroblasts [297], tumor-associated macrophages [298], tumor-associated neutrophils [299], mesenchymal-associated cells [300], and cell-mediated adhesion and soluble factors [301], which played important roles in cell-cell communication.

\section{How to avoid tumorigenesis in human pluripotent stem cells}

Tumor suppressor genes are mostly transcription factors that modulate the antiproliferation signals that arrest the consistency of the cell cycle for DNA repair and that prevent mutation during cell division [302-306]. For example, the p53 tumor suppressor gene protein product functions as a transcription factor and a cytoplasmic regulator in cell cycle arrest and apoptosis [306-308]. The dysregulation of genes that modulate the cell cycle results in uncontrolled cell division, during which a series of mutations to proto-oncogenes and tumor suppressors are needed before cells transform to cancerous cells [309]. Proto-oncogenes are quiescent counterparts of oncogenes that become oncogenes upon mutation. The modified cells produce more of the gene product and exhibit excessive proliferative ability. Hormones or signal transduction can stimulate oncogenes to promote uncontrolled cell proliferation by changing the regulation of gene transcription [310, 311].

Pluripotent reprogramming factors are overexpressed in various cancers [312, 313]. OCT4 has been reported to be overexpressed in a gastric cell line [18], ovarian carcinoma, pancreatic cancer [18], prostate cancer [314], and bladder cancer [315]. c-MYC is also overexpressed in various cancers [316, 317] and can block differentiation and induce tumor formation in the absence of p53 $[318,319]$. These observations indicate that reprogramming factors can act as potential proto-oncogenes in the reprogramming process and emphasize the potential risk of carcinogenesis by stem cell-like cells.

\section{Reprogramming}

Reprogramming protocols have been used to inhibit the tumorigenesis induced during reprogramming in studies of various cancer cells [20-22]. In these models, one or multiple sets of reprogramming factors are delivered to cancer cells and induced patient specific CSCs are generated. These models can be used to study therapeutic targets in the initial stage of carcinogenesis [20-22]. In addition to the genetic methods that are used to generate pluripotent stem cells, some small molecules have been reported to promote cell reprogramming. For example, targeting signaling pathways like the HDAC, Wnt, and TGF $\beta$ cascades can regulate the expression of pluripotent stemness genes induce the reprogramming of cells [25]. Various molecules that promote reprogramming can replace genetic methods; these include recombinant reprogramming factors (OSKM) with polyarginine tags [26] and other small molecules [30-33]. However, chemically defined small molecules that induce reprogramming alone have not been developed for human induced pluripotent stem cells (hiPSCs) [24]. Furthermore, whether small molecule-driven iPSCs can prevent the risk of tumorigenesis when used therapeutically has not been determined. The ability of undifferentiated iPSCs to produce teratomas in grafted cell populations is one of the main concerns of this approach, and the nature of these cells should be clarified genetically. Precise information about these transplantation animal models, inoculated patient-specific iPSCs, and the resultant organoids is needed.

\section{Reversibility of the epigenetic state}

The use of clones that have been pre-evaluated as being safe is one possibility for overcoming carcinogenic activity, as demonstrated in neural stem cells (NSCs) [320322]. An antibody against SSEA-5 on human ESCs (hESCs) can be utilized to remove teratoma-forming cells from dissociated hESCs [323]. In immune-deficient mice, flow cytometric analysis has shown that transplants of SSEA-5-negative cells formed smaller teratomas, measuring $<1 \mathrm{~cm}^{3}$, whereas SSEA-5-positive transplanted cells formed teratomas $>1 \mathrm{~cm}^{3}$. Flow cytometric analysis using an anti-SSEA-5 antibody may be useful for separating undifferentiated, unsafe cells from iPSC-driven mixed-cell populations. The induction of senescence generated by replication stress and DNA damage, telomere shortening, environmental and oncogenic stresses, and the pro- inflammation inducing microenvironments is one of the oncogene-associated events involving epigenetic control [285]. Cancer-associated senescence has been reported to promote cancer stemness and plasticity in CSCs [306].

\section{Risk management to prevent tumorigenesis}

Three different approaches for the removal of tumorinitiating pluripotent stem cells from ESCs and their 
differentiated cells have been reported: (i) chemical treatment [324-327], (ii) genetic treatment [328-330], and (iii) immunological treatment [323, 331-335] (Table 2). Each method has its advantages and disadvantages; the latter include the high cost, variation between lots, nonspecific antibody binding, integration of toxic genes, and long duration [354]. A strategy for application to clinics to abate the teratoma formation should be explored further [354, 355]. The use of small molecules has several advantages, such as robustness, efficiency, speed, simplicity, and low cost. Some small molecules can inhibit the formation of teratoma in human pluripotent stem cells (hPSCs). For example, an inhibitor of stearoyl-CoA desaturase (SCD), PluriSIns \#1, has been shown to prevent teratoma formation [325]. SCD1 is an important enzyme in the biochemical synthesis of monosaturated fatty acids, which are needed for the survival of hPSCs. A recent study reported that SCDs play a critical role in endoplasmic reticulum (ER) stress and promote the survival of glioblastoma cancer stem cells [356]. The N-benzylnonanamide JC101 induces ER stress via the protein kinase RNA-like endoplasmic reticulum kinase/ATF4/DNA damage inducible transcript 3 (DDIT3 $=$ CHOP) pathway [340], which leads to the inhibition of teratoma formation. In a study that used iPSCs to treat spinal cord injury, these cells were determined to be safe before the grafting of transplants, which prevented the formation of teratomas [357].

The introduction of inhibitors of antiapoptotic factors that effectively remove residual iPSCs can also prevent teratoma formation $[344,348]$. Treatment with survivin (an antiapoptotic factor) and a novel survivin suppressant, YM155, was effective in decreasing the risk of teratoma formation. In that study, addition of YM155 permitted the survival of $\mathrm{CD} 34^{+}$cord blood cells and prevented teratoma formation in human induced pluripotent stem cells (hiPSCs)-grafted mice [347].

The introduction of inducible caspase-9 (iCap9), as a suicide gene, into hiPSCs avoided tumorigenic transformation after their transplantation [347, 348]. The efficiency of iCap9 and small molecule-like chemically induced dimerization (CID) in the prevention of the risk of tumorigenesis was evaluated in cell-transplantation experiments. iCap9 integrated with CID induced the apoptosis of iPSCs and iPSC-derived NSCs and produced the terminal differentiation of transduced cells grafted into injured spinal cord in mice but avoided the formation of teratomas [348].

A conditionally replicating adenovirus that targets cancers using multiple factors ( $m$-CRAs) is a new antitumorigenic agent used in hPSC-based cell therapy. Given that the survivin promoter is stronger in undifferentiated hPSCs than was the telomerase reverse transcriptase (TERT) promoter, surviving promoter m-CRAs efficiently kill undifferentiated hPSCs but not differentiated normal cells when compared with TERT promoter m-CRAs. The surviving promoter $\mathrm{m}$-CRAs seems to be a novel antitumorigenic agent that may facilitate safer hPSC-based medical applications [358].

Another approach is the isolation of the desired differentiated cells from other cell types and undifferentiated hPSCs, such as the removal method of the residual pluripotent cells from other cells using fluorescence-activated cell sorting or antibodies coated magnetic beads against a particular antigen, including SSEA-5 [323], claudin-6 [333, 359], and the Ulex europaeus agglutinin-1 fucose-binding lectin (UEA) [360]. Caludin-6 bound to the enterotoxin produced by Clostridium perfringens kills the hPSCs that induce teratoma formation [333]. Yet another approach is the direct, targeted killing of tumor cells using a cytotoxic antibody against the podocalyxin-like protein-1, an inhibitor of stearoyl-CoA desaturases or a DNA topoisomerase II inhibitor, etc. Etoposide, a DNA topoisomerase II inhibitor, and the CDK inhibitor purvalanol have been used to minimize the risks of tumor formation by posttransplanted ESCs and iPSCs $[345,346]$. Lin et al. reported that the cardiac glycosides digoxin and lanatoside $\mathrm{C}$ can kill undifferentiated hESCs [339].

\section{Important effects of JDP2 on reprogramming-derived CSCs}

The activation of the Wnt signaling is critical for maintaining of pluripotency in ESCs [41, 185, 186, 192, 193]. JDP2, has been used as a pluripotency-promoting factor in the reprogramming of cancer cells to reduce their cancerous features. JDP2 can activate or repress various gene transcription actions [185, 361], although it also plays a critical role in malignant transformation. For example, JDP2 can promote cancer cell growth in leukemia and hepatocellular carcinoma [362, 363] but may also be a tumor suppressor in cancer cells $[159,364]$. The treatment of gastric cancer cell lines with OCT4 and JDP2 inhibited the tumorigenic function of the cells by switching off BMP7 [195, 365]. The tumor-forming ability of these partially reprogrammed gastric CSC-like cells is reduced in immune-deficient mice, which shows that JDP2 plays a critical role in the reduction of oncogenic potential $[185,189]$.

Double deficiency of ATF3 and Jdp2 in mice stromal tumors promotes cancer growth [361]. Jdp2 is regarded as a factor that drives reprogramming through the regulation of the Wnt signaling pathway and the suppression of ROS production [188]. Oxygen regulates pluripotent stem cells via Wnt- $\beta$-catenin signaling and HIF- $1 \alpha$ [188]. Wnt signaling plays a key role in the generation and maintenance of iPSCs [366]. JDP2 is one of the target genes of the $L E F-T C F$ family and is involved in the Wnt signaling pathway [185]. Wang et al. generated iPSC-like cells by introducing OCT4 and JDP2 (JO) into 


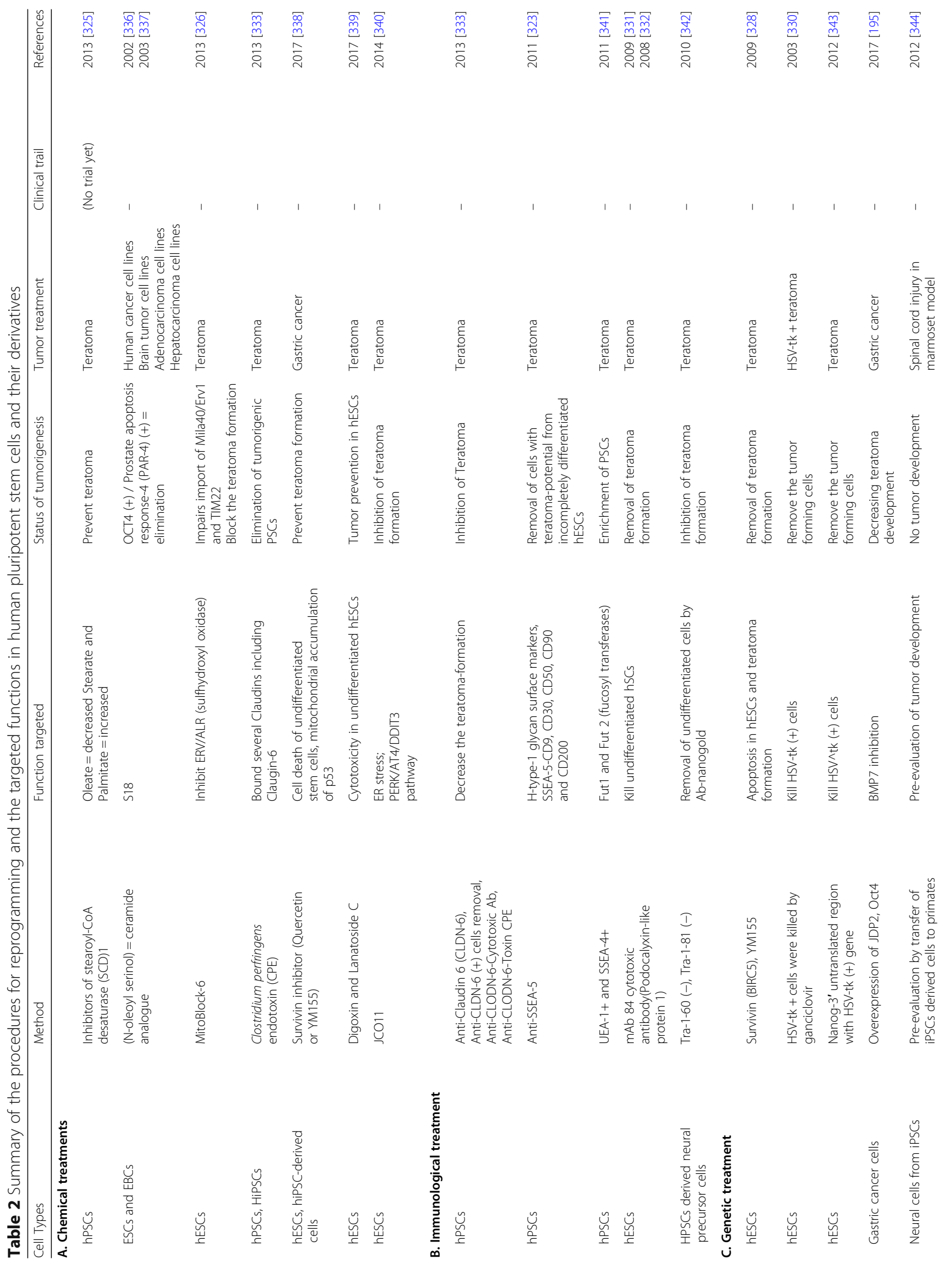




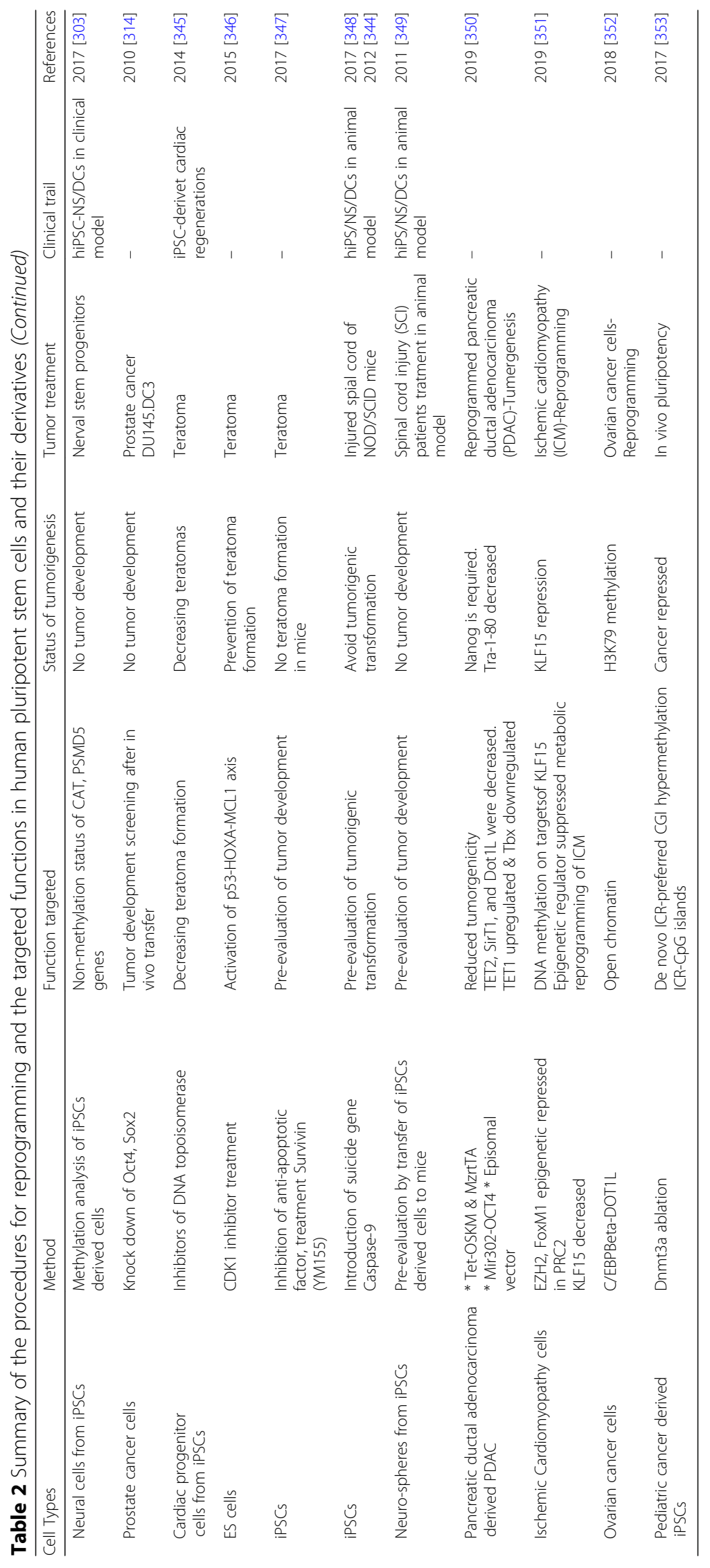


gastric cancers for reprogramming [306]. ESC-like colonies were obtained in teratomas of JO-introduced xenografts. The JO-introduced xenografts were smaller and had fewer necrotic and mitotic cells, and a larger nucleus, than the parent cancer xenografts.

The roles of EZH2, HMT, and MLL in the regulation of BMP7 expression have been examined [364, 365]. The findings of this study suggest that HMT inhibitors can be used to prevent MLL and that EZH2 is a potential therapeutic target. The $\beta$-catenin-JDP2-RPMT5 complex axis is critical for reestablishing glutathione homeostasis after genotoxic-mediated stress and may be useful in the development of drugs aimed at treating or avoiding inducible resistance to chemotherapy in cancer cells [367]. A combination of factors (Jdp2, Jhdm1b, Mkk6, Glis1, Nanog, Essrb, and Sall4) was reported to be a useful reprogramming complex for efficiently leading mouse embryonic fibroblasts (MEFs) to become chimeracompetent iPSCs in xenografts [368]. These findings suggest that the direct reprogramming of stem cells cannot reduce the risk of malignancy itself, and that excluding cancer cells from the microenvironment of stem cells may be crucial for reducing the risk of cancer.

\section{Other solutions to eliminate the risk of tumorigenesis}

Methods of pluripotency reprogramming that do not use genetic material provide another potential strategy for generating safe iPSCs. To date, various molecules that promote cell reprogramming have been reported as substitutes for genetic materials. These small molecules modulate the activities of the enzymes that are involved in the epigenetic modification of genes and may play a crucial role in pluripotency reprogramming $[25,27-30$, 369]. These small molecules include the TGF $\beta$ inhibitory antagonist SB431542, the MAPK-extracellular signalregulated kinase inhibitor PD0325901, and the inhibitor of Rho-associated coiled-coil-containing protein kinase thiazovivin (2,4-disubstituted thiazole or TZV). TZV significantly increases the rate of hiPSC reprogramming by up to 200-fold [370]. The combination of Oct4, the TGF $\beta$ receptor inhibitor A83-01, and the methyltransferase inhibitor AMI-5 increases the reprogramming efficiency of mouse iPSCs, and the repression of ROS increases the efficiency of cell reprogramming [371, 372]. The addition of vitamin $C$ to the culture medium significantly increases the reprogramming efficiency. However, the generation of hiPSCs using small-molecule compounds alone has not been shown to reduce the risk of tumorigenesis significantly. Further investigation of nongenetic compound-guided iPSCs is required to exclude the potential for tumor progression before patient engraftment.

Vitamin $\mathrm{C}$ is a candidate for preventing the tumorigenesis caused by hiPSCs because it inhibits the improper self-renewal of human stem cells by increasing histone demethylase activity. Vitanin $\mathrm{C}$ has also been applied as an anticancer agent in melanomas [373-376]. The histone demethylases JIhdm $1 \mathrm{a} / 1 \mathrm{~b}$ are the direct downstream molecules of vitamin $C$. In addition to its antioxidant activity [376], vitamin $C$ was reported to increase the rate of reprogramming of fibroblasts to iPSCs when added to the culture medium [190]. In that study, supplementation with vitamin $C$ decreased p53/p21 levels, which successfully blocked pluripotency reprogramming.

The mutation frequencies in hiPSCs increases with age. Aging is also one of the major risk factors for cancer progression. Therefore, younger donor cells may be used to avoid detrimental mutations in mitochondrial DNA. The reprogramming of somatic cells into iPSCs resets the cellular damage and the stress- and senescenceassociated epigenetic marks in vitro, which suggests that the reprogramming technology may be able to induce the rejuvenation of senescent cells [377]. Mosteiro et al. reported that cells reprogrammed in vitro were present next to senescent cells clustered in reprogrammable mice [378]. These senescent cells promote reprogramming through senescence-associated secretory phenotypes, especially via the production of interleukin 6 [379]. The functional crosstalk between reprogramming and senescence has been reported elsewhere [380, 381].

To avoid the risk of point mutations in stem cells, histocompatibility antigen-matched umbilical cord blood-derived iPSCs are useful for ensuring a minimal rate of mutations [382]. Amniotic cells derived from human placental tissues exhibit lower immunogenicity and anti-inflammatory properties than do other cells [383, 384]. The expression of putative immunosuppressors, such as CD59 and CD73, is repressed during the process of reprogramming in amniotic cells [385]. These findings emphasize that long-term-cultured hESCs and hiPSCs show increased growth rates and decreased dependence on the concentration of growth factors and malignant tumor-forming abilities after their engraftment in mice [386]. Carcinoma-derived iPCSCs, which have a higher number of passages, exhibit increased carcinogenic ability compared with those obtained from donor cholangiocellular carcinoma [387].

Other candidate for therapeutic agents includes drugs against the super-enhancers involved in phase separation [388]. In general, the machinery used for epigenetic modification can be altered during transcription initiation, elongation, and termination by involving the transcriptional complex containing polymerase II. Transcriptional regulators such as the mediator MED, coactivator Brd4, splicing factor SRSF2, histone heterochromatin protein 1, and nucleoplasmin 1 may be targets for therapies aimed at modulating chromatin structure during reprogramming and for blocking the development of cancer or other 
genetic diseases [389]. Hepatocellular carcinomas (HCCs) exhibit distinct promoter hypermethylation patterns. Deletion of $\mathrm{C} / \mathrm{EBP} \beta$ expression using the CRISPR-Cas9 system affects the co-recruitment of BRD4 at enhancers marked with H3K27ac to block the development of HCC [390].

The two mediator kinases, CDK8 and CDK19, may enable transcriptional reprogramming through the superenhancer family, chromatin looping by CTCF, and cohesion with the transcriptional mediators MED12 and 13, which may be potential drug targets [391]. The valproic acid-mediated inhibition of HDAC and glycogen synthase kinase- 3 results in the transcriptional repression of many genes, including the gene that encodes for myristoylated alanine-rich C-kinase substrate 1 , which is the Actinstabilizing protein that is required for the process of the early development of dendritic morphogenesis and synapse maturation [392]. In zebrafish, p300 and Brd4 trigger genome-wide transcriptional network by controlling histone acetylation of the first zygotic genes. This mechanism is crucial for initiation of zygotic development and reproduction [393]. In mammals, these target genes are also potential candidates for drug targets. Stem cellderived organoids may also be useful for identifying the effects of the microenvironmental niche on cancer development and the reprogramming fates of stem cells [394].

The successful epigenetic reprogramming of primary cancerous cells was recently reported [350]. Pancreatic ductal adenocarcinoma cells were reprogrammed by independent protocols, such as the introduction of OCT4 together with miRNA of Mir302, the episomal vectorencoded NANOG and REX1, in Yamanaka's protocol (as a control). These methods yielded efficient reprogramming with reduced tumorigenicity through epigenetic changes, such as downregulation of TET2, SIRT1, disruptor of telomeric silencing 1-like (DOT1L), and T-box 3 (TBX3) and upregulation of TET1. A study of ischemic cardiomyopathy found that DNA methylation and the metabolic pathway were strongly correlated through the EZH2-KLF15 axis [351]. C/EBP $\beta$ recruits the DOT1L methyltransferase to open chromatin via methylation of H3K79 in multiple drug-resistance genes [352].

Imprint dysregulation compromises the developmental ability of pluripotent stem cells [353]. The stability of de novo methylation of CpG islands in PSCs is critical for cancer development. Thus, CpG islands and imprintingcontrol regions are important for the evaluation of development, stemness, and pluripotency [395]. Reprogrammed hiPSCs exhibit greater loss of imprinting compared with ESCs, and the loss of imprinting preexists in their somatic cells of origin. The differently imprinted genes related to the loss of imprinting, especially those of paternal control, are more prone to disruption [396].

Ubiquitin-like with PHD and RING finger domain 1 (Uhrf1) is a hemimethylated DNA-binding protein that interacts with DNMT1 and recruits euchromatic histone-lysine $\mathrm{N}$-methyltransferase 2 to form heterochromatin, together with tripartite motif-containing 28 and HDACs, for DNA methylation. In mouse stem cells, Uhrf1 interacts with the SET domain complex containing 1A/COMPASS, followed by positive regulation of H3K4me3 modification. Uhrf1 maintains bivalent histone marks, such as H3K27me3 and H3K4me3, and particularly those associated with specifications to the neuroectoderm and mesoderm [396]. Tatton-BrownRahman syndrome (TBRS) is caused by a mutation in $D N M T 3 A$, a gene that is also associated with Sotos syndrome, which is caused by haploinsufficiency of NSD1, an HMT that catalyzes the demethylation of histone $\mathrm{H} 3$ at K36 (H3K36m22). In the mouse, NSD1-mediated H3K36me2 methylation is induced by the recruitment of DNMT3A and is crucial for the maintenance of DNA methylation at intergenic regions. The binding of DNMT3A to H3K36me2 can be inhibited by a missense mutation associated with TBRS, which suggests that trans-chromatin regulatory control is critical for human neoplastic and developmental growth [397].

\section{Conclusion}

Genetic or epigenetic alterations in proteins or microenvironmental niches might promote the initiation or progression of carcinogenesis in some cells. Further steps should be taken to provide effective anticancer systems for the therapeutic application of reprogramming-guided human stem cells. One intriguing technique is the use of a CRISPR-Cas-derived vector to remove the targeted region of epigenetic barriers to identify the effects of transcriptional reprogramming. Targeting of dCAS9-VP64 to the Sox 1 promoter produces strict transcript and protein upregulation in neural progenitor cells. The removal of DNA methylation by dCas9-Tet1 increases the proportion of cells with activating master key transcription factors for abrogating the barriers of cell fate [398]. The single-cell sequencing technique is also critical for defining cell fate and the decision toward differentiation.

The ascorbic acid plus 2i and Dot1l inhibitor drugs can rapidly affect the conversion of MEFs to iPSCs. The stemness gene Nanog appears in a subcluster with genes such as those encoding the epithelial cell adhesion molecule (Epcam), Sal-like protein 4 (Sall4), and thymine DNA glycosylase genes (Tdg). The Tdg tandem duplicate 1 (Tdg1) and Oct4 cluster with Zfp 42, and Sox2 clusters with the undifferentiated embryonic cell transcription factor 1 (Utf1) and the developmental pluripotencyassociated protein 5A (Dppa5a). Sustained coexpression of Epcam, Nanog, and Sox 2 with other genes is also required for progression of MEFs toward iPSCs. The genes for Ets homologous factor (Ehf), pleckstrin homologylike domain family A member 2 (Phlda2), and eukaryotic 
initiation factor 4A-I (Eif4a1) also play critical roles in robust iPSC generation.

Regulatory network analyses allow the search for new networks of signaling, such as signaling inhibition by $2 \mathrm{i}$, and their role in repressing somatic expression. Such analyses also allow the comparison of the actions of the epigenetic modifier ascorbic acid and a Dot1l inhibitor for pluripotent gene activation [399]. In one study, human iPSC-derived neurospheres were transferred into nonobese diabetic-severe combined immune-deficient mice, to treat and cure a spinal cord injury without any tumor generation [349]. These grafted hiPSC-NSs survived, migrated, and differentiated into functional neurons. However, the direct application of undifferentiated iPSCs or hPSCs to patients has not been reported and further research and advances are needed to generate transplantable stem cells or organoids that can be applied to patients in the near future.

Collectively, the data discussed in this review show that the characteristics of pluripotency can inhibit the features of the cancer phenotype, restore differentiation potential, and change the expression of the indicated cancer-related genes through epigenetic modifications, chromatin organization, and metabolism reprogramming (Table 2). Therefore, the targeting of these epigenetic alterations may provide effective approaches for inhibiting the tumorigenic capability of CSCs in the future. Further study is required to provide further understanding of the molecular machineries underlying the reprogramming of cancer cells and the development of novel therapies for the regenerative reprogramming of human cancer cells and their derived organoids.

\section{Abbreviations}

BMP7: Bone morphogenetic protein 7; CNVs: Copy number variations; CSCs: Cancer stem cell; DNMT: DNA methyltransferase; EMT: Epithelial mesenchymal transition; ESCs: Embryonic stem cells; EZH2: Enhancer of zesta; HDAC: Histone deacetylase; hESCs: Human embryonic stem cells; hiPSCs: Human induced pluripotent stem cells; iPSCs: Induced pluripotent stem cells; JDP2: Jun dimerization protein 2; miRNA: MicroRNA; OSKM: Oct4, Sox2, Klf4 and c-Myc; OSNL: Oct4, Sox2, Nanog, and Lin28;

PGE2: Prostaglandin E2; PRC: Polycomb repressive complex; PSC: Pluripotent stem cells; ROS: Reactive oxygen species; SCD: stearoyl-CoA desaturase;

TERT: Telomerase reverse transcriptase; TET: Ten-eleven translocation protein; TGF $\beta$ : Transforming growth factor $\beta$

\section{Acknowledgments}

We thank JB Pan for useful discussions during the editing of this manuscript.

\section{Authors' contributions}

Design of the review and drafting of the manuscript, KW, CCK, DCW, YCL, KK, SS, and KKY.; Compilation of the documentation materials, KW, CCK, KK, YCL, DCW, SS, and KKY. The authors read and approved the manuscript. Moreover, all authors agreed to add Dr. K. Kato as the co-author by his contribution to this review article.

\section{Funding}

This work was supported partially by grants from the Ministry of Science and Technology (MOST 107-2314-B-037-085, MOST 107-2320-B-037-026, and MOST 108-2320-B-037-005); the National Health Research Institutes (NHRIEx108-10720SI); and Kaohsiung Medical University (KMU-TC108A02).
Availability of data and materials

Not applicable.

Ethics approval and consent to participate

Not applicable.

Consent for publication

Not applicable.

\section{Competing interests}

The authors declare no conflict of interests.

\section{Author details}

${ }^{1}$ Graduate Institute of Medicine, Kaohsiung Medical University, 100 Shih-Chuan 1st Rd., San-Ming District, Kaohsiung 807, Taiwan. ${ }^{2}$ Regenerative Medicine and Cell Therapy Research Center, Kaohsiung Medical University Hospital, Kaohsiung 807, Taiwan. ${ }^{3}$ Division of Gastroenterology, Department of Internal Medicine, Kaohsiung Medical University Hospital, Kaohsiung 807 Taiwan. ${ }^{4}$ School of Dentistry, School of Medicine, Kaohsiung Medical University, Kaohsiung 807, Taiwan. ${ }^{5}$ Waseda University Research Institute for Science and Engineering, Shinjuku, Tokyo 162-8480, Japan. ${ }^{6}$ Saito Laboratory of Cell Technology Institute, Yaita, Tochigi 329-1571, Japan.

Received: 20 January 2020 Accepted: 22 April 2020

Published online: 03 June 2020

\section{References}

1. Campbell KH, McWhir J, Ritchie WA, Wilmut I. Sheep cloned by nuclear transfer from a cultured cell line. Nature. 1996;380(6569):64-6.

2. Takahashi K, Tanabe K, Ohnuki M, Narita M, Ichisaka T, Tomoda K, et al. Induction of pluripotent stem cells from adult human fibroblasts by defined factors. Cell. 2007;131(5):861-72.

3. Takahashi K, Yamanaka S. Induction of pluripotent stem cells from mouse embryonic and adult fibroblast cultures by defined factors. Cell. 2006;126(4): 663-76.

4. Yu J, Hu K, Smuga-Otto K, Tian S, Stewart R, Slukvin II, et al. Human induced pluripotent stem cells free of vector and transgene sequences. Science. 2009;324(5928):797-801.

5. Yu J, Vodyanik MA, Smuga-Otto K, Antosiewicz-Bourget J, Frane JL, Tian S, et al. Induced pluripotent stem cell lines derived from human somatic cells. Science. 2007;318(5858):1917-20.

6. Boumahdi S, Driessens G, Lapouge G, Rorive S, Nassar D, Le Mercier M, et al. SOX2 controls tumour initiation and cancer stem-cell functions in squamous-cell carcinoma. Nature. 2014;511(7508):246-50.

7. Chen Y, Shi L, Zhang L, Li R, Liang J, Yu W, et al. The molecular mechanism governing the oncogenic potential of SOX2 in breast cancer. J Biol Chem. 2008;283(26):17969-78.

8. Hart AH, Hartley L, Parker K, Ibrahim M, Looijenga LH, Pauchnik M, et al. The pluripotency homeobox gene NANOG is expressed in human germ cell tumors. Cancer. 2005;104(10):2092-8.

9. Hochedlinger K, Yamada Y, Beard C, Jaenisch R. Ectopic expression of Oct-4 blocks progenitor-cell differentiation and causes dysplasia in epithelial tissues. Cell. 2005;121(3):465-77.

10. Okita K, Ichisaka T, Yamanaka S. Generation of germline-competent induced pluripotent stem cells. Nature. 2007:448(7151):313-7.

11. Peng S, Maihle NJ, Huang Y. Pluripotency factors Lin28 and Oct4 identify a sub-population of stem cell-like cells in ovarian cancer. Oncogene. 2010; 29(14):2153-9.

12. Saha K, Jaenisch R. Technical challenges in using human induced pluripotent stem cells to model disease. Cell Stem Cell. 2009;5(6):584-95.

13. Barker $\mathrm{N}$, Ridgway RA, van Es $\mathrm{JH}$, van de Wetering $M$, Begthel $H$, van den Born M, et al. Crypt stem cells as the cells-of-origin of intestinal cancer. Nature. 2009:457(7229):608-U119.

14. Yilmaz A, Benvenisty N. Defining Human Pluripotency. Cell Stem Cell. 2019; 25(1):9-22.

15. Monk M, Holding C. Human embryonic genes re-expressed in cancer cells. Oncogene. 2001;20(56):8085-91.

16. Zhao W, Ji X, Zhang F, Li L, Ma L. Embryonic stem cell markers. Molecules. 2012;17(6):6196-236.

17. Zhao W, Li Y, Zhang X. Stemness-Related Markers in Cancer. Cancer Transl Med. 2017:3(3):87-95. 
18. Schoenhals M, Kassambara A, De Vos J, Hose D, Moreaux J, Klein B. Embryonic stem cell markers expression in cancers. Biochem Biophys Res Commun. 2009;383(2):157-62.

19. Hepburn AC, Steele RE, Veeratterapillay R, Wilson L, Kounatidou EE, Barnard $A$, et al. The induction of core pluripotency master regulators in cancers defines poor clinical outcomes and treatment resistance. Oncogene. 2019; 38(22):4412-24.

20. Miyoshi N, Ishii H, Nagai K, Hoshino H, Mimori K, Tanaka F, et al. Defined factors induce reprogramming of gastrointestinal cancer cells. Proc Natl Acad Sci U S A. 2010;107(1):40-5.

21. Carette JE, Pruszak J, Varadarajan M, Blomen VA, Gokhale S, Camargo FD, et al. Generation of iPSCs from cultured human malignant cells. Blood. 2010; 115(20):4039-42

22. Ramos-Mejia V, Fraga MF, Menendez P. iPSCs from cancer cells: challenges and opportunities. Trends Mol Med. 2012;18(5):245-7.

23. Koren S, Reavie L, Couto JP, De Silva D, Stadler MB, Roloff T, et al. PIK3CA(H1047R) induces multipotency and multi-lineage mammary tumours. Nature. 2015;525(7567):114-8.

24. Kuo KK, Lee KT, Chen KK, Yang YH, Lin YC, Tsai MH, et al. Positive Feedback Loop of OCT4 and c-JUN Expedites Cancer Stemness in Liver Cancer. Stem Cells. 2016;34(11):2613-24.

25. Hou P, Li Y, Zhang X, Liu C, Guan J, Li H, et al. Pluripotent stem cells induced from mouse somatic cells by small-molecule compounds. Science. 2013;341(6146):651-4.

26. Zhou H, Wu S, Joo JY, Zhu S, Han DW, Lin T, et al. Generation of induced pluripotent stem cells using recombinant proteins. Cell Stem Cell. 2009;4(5): $381-4$.

27. Feng $\mathrm{B}, \mathrm{Ng} \mathrm{JH}$, Heng JC, $\mathrm{Ng} \mathrm{HH}$. Molecules that promote or enhance reprogramming of somatic cells to induced pluripotent stem cells. Cell Stem Cell. 2009;4(4):301-12.

28. Firestone AJ, Chen JK. Controlling destiny through chemistry: smallmolecule regulators of cell fate. ACS Chem Biol. 2010;5(1):15-34

29. Higuchi A, Ling QD, Kumar SS, Munusamy MA, Alarfaj AA, Chang Y, et al. Generation of pluripotent stem cells without the use of genetic material. Lab Invest J Technical Methods Pathol. 2015;95(1):26-42.

30. Huangfu D, Maehr R, Guo W, Eijkelenboom A, Snitow M, Chen AE, et al. Induction of pluripotent stem cells by defined factors is greatly improved by small-molecule compounds. Nat Biotechnol. 2008;26(7):795-7.

31. Li X, Xu J, Deng H. Small molecule-induced cellular fate reprogramming: promising road leading to Rome. Curr Opin Genet Dev. 2018;52:29-35.

32. Papaccio F, Paino F, Regad T, Papaccio G, Desiderio V, Tirino V. Concise Review: Cancer Cells, Cancer Stem Cells, and Mesenchymal Stem Cells: Influence in Cancer Development. Stem Cells Transl Med. 2017;6(12):2115-25.

33. Zhu S, Li W, Zhou H, Wei W, Ambasudhan R, Lin T, et al. Reprogramming of human primary somatic cells by OCT4 and chemical compounds. Cell Stem Cell. 2010;7(6):651-5.

34. Deng J, Zhang Y, Xie Y, Zhang L, Tang P. Cell Transplantation for Spinal Cord Injury: Tumorigenicity of Induced Pluripotent Stem Cell-Derived Neural Stem/Progenitor Cells. Stem Cells Int. 2018;2018:5653787.

35. Liu H, Luo J, Luan S, He C, Li Z. Long non-coding RNAs involved in cancer metabolic reprogramming. Cell Mol Life Sci. 2019;76(3):495504.

36. Zhang Z, Zhuang L, Lin CP. Roles of MicroRNAs in Establishing and Modulating Stem Cell Potential. Int J Mol Sci. 2019;20(15):3643.

37. Evans MJ, Kaufman MH. Establishment in culture of pluripotential cells from mouse embryos. Nature. 1981;292(5819):154-6.

38. Abad M, Mosteiro L, Pantoja C, Canamero M, Rayon T, Ors I, et al. Reprogramming in vivo produces teratomas and iPS cells with totipotency features. Nature. 2013;502(7471):340-5.

39. Niwa $\mathrm{H}$. The pluripotency transcription factor network at work in reprogramming. Curr Opin Genet Dev. 2014;28:25-31.

40. Niwa H, Burdon T, Chambers I, Smith A. Self-renewal of pluripotent embryonic stem cells is mediated via activation of STAT3. Genes Dev. 1998; 12(13):2048-60.

41. Sato N, Meijer L, Skaltsounis L, Greengard P, Brivanlou AH. Maintenance of pluripotency in human and mouse embryonic stem cells through activation of Wnt signaling by a pharmacological GSK-3-specific inhibitor. Nat Med. 2004;10(1):55-63.

42. Blauwkamp TA, Nigam S, Ardehali R, Weissman IL, Nusse R. Endogenous Wnt signalling in human embryonic stem cells generates an equilibrium of distinct lineage-specified progenitors. Nat Commun. 2012;3:1070.
43. Qu Q, Sun G, Li W, Yang S, Ye P, Zhao C, et al. Orphan nuclear receptor TLX activates Wnt/beta-catenin signalling to stimulate neural stem cell proliferation and self-renewal. Nat Cell Biol. 2010;12(1):31-40 sup pp 1-9.

44. Lukacs RU, Memarzadeh S, Wu H, Witte ON. Bmi-1 is a crucial regulator of prostate stem cell self-renewal and malignant transformation. Cell Stem Cell. 2010;7(6):682-93.

45. Malanchi I, Santamaria-Martinez A, Susanto E, Peng H, Lehr HA, Delaloye JF, et al. Interactions between cancer stem cells and their niche govern metastatic colonization. Nature. 2011;481(7379):85-9.

46. Pacheco-Pinedo EC, Durham AC, Stewart KM, Goss AM, Lu MM, Demayo FJ, et al. Wnt/beta-catenin signaling accelerates mouse lung tumorigenesis by imposing an embryonic distal progenitor phenotype on lung epithelium. J Clin Invest. 2011;121(5):1935-45.

47. Paluszczak J. The Significance of the Dysregulation of Canonical Wnt Signaling in Head and Neck Squamous Cell Carcinomas. Cells. 2020;9(3):723.

48. Heo JS, Lee MY, Han HJ. Sonic hedgehog stimulates mouse embryonic stem cell proliferation by cooperation of $\mathrm{Ca} 2+$ /protein kinase $\mathrm{C}$ and epidermal growth factor receptor as well as Gli1 activation. Stem Cells. 2007;25(12):3069-80

49. Wu SM, Choo AB, Yap MG, Chan KK. Role of Sonic hedgehog signaling and the expression of its components in human embryonic stem cells. Stem Cell Res. 2010;4(1):38-49.

50. Clement V, Sanchez P, de Tribolet N, Radovanovic I, Ruiz i Altaba A. HEDGEHOG-GLI1 signaling regulates human glioma growth, cancer stem cell self-renewal, and tumorigenicity. Current Biol. 2007;17(2):165-72.

51. Feldmann G, Dhara S, Fendrich V, Bedja D, Beaty R, Mullendore M, et al. Blockade of hedgehog signaling inhibits pancreatic cancer invasion and metastases: a new paradigm for combination therapy in solid cancers. Cancer Res. 2007:67(5):2187-96.

52. Liu S, Dontu G, Mantle ID, Patel S, Ahn NS, Jackson KW, et al. Hedgehog signaling and Bmi-1 regulate self-renewal of normal and malignant human mammary stem cells. Cancer Res. 2006;66(12):6063-71.

53. $\mathrm{Xu} Y$, Song $\mathrm{S}$, Wang $Z$, Ajani JA. The role of hedgehog signaling in gastric cancer: molecular mechanisms, clinical potential, and perspective. Cell Commun Signaling. 2019;17(1):157.

54. Lowell S, Benchoua A, Heavey B, Smith AG. Notch promotes neural lineage entry by pluripotent embryonic stem cells. PLoS Biol. 2006;4(5):e121.

55. Rizzo P, Osipo C, Foreman K, Golde T, Osborne B, Miele L. Rational targeting of Notch signaling in cancer. Oncogene. 2008:27(38):5124-31.

56. Fan X, Matsui W, Khaki L, Stearns D, Chun J, Li YM, et al. Notch pathway inhibition depletes stem-like cells and blocks engraftment in embryonal brain tumors. Cancer Res. 2006;66(15):7445-52.

57. Sikandar SS, Pate KT, Anderson S, Dizon D, Edwards RA, Waterman ML, et al. NOTCH signaling is required for formation and self-renewal of tumorinitiating cells and for repression of secretory cell differentiation in colon cancer. Cancer Res. 2010;70(4):1469-78.

58. Ayyanan A, Civenni G, Ciarloni L, Morel C, Mueller N, Lefort K, et al. Increased Wnt signaling triggers oncogenic conversion of human breast epithelial cells by a Notch-dependent mechanism. Proc Natl Acad Sci U S A. 2006:103(10):3799-804

59. Abel EV, Kim EJ, Wu J, Hynes M, Bednar F, Proctor E, et al. The Notch pathway is important in maintaining the cancer stem cell population in pancreatic cancer. PLoS One. 2014;9(3):e91983.

60. Ogawa K, Saito A, Matsui H, Suzuki H, Ohtsuka S, Shimosato D, et al. ActivinNodal signaling is involved in propagation of mouse embryonic stem cells. J Cell Sci. 2007;120(Pt 1):55-65.

61. James D, Levine AJ, Besser D, Hemmati-Brivanlou A. TGFbeta/activin/nodal signaling is necessary for the maintenance of pluripotency in human embryonic stem cells. Development. 2005;132(6):1273-82.

62. Schober M, Fuchs E. Tumor-initiating stem cells of squamous cell carcinomas and their control by TGF-beta and integrin/focal adhesion kinase (FAK) signaling. Proc Natl Acad Sci U S A. 2011; 108(26):10544-9.

63. Oshimori N, Fuchs E. The harmonies played by TGF-beta in stem cell biology. Cell Stem Cell. 2012;11(6):751-64.

64. Zhang Y, Que J. BMP Signaling in Development, Stem Cells, and Diseases of the Gastrointestinal Tract. Annu Rev Physiol. 2020;82:251-73.

65. Bhola NE, Balko JM, Dugger TC, Kuba MG, Sanchez V, Sanders M, et al. TGFbeta inhibition enhances chemotherapy action against triple-negative breast cancer. J Clin Invest. 2013;123(3):1348-58. 
66. Chruscik A, Gopalan V, Lam AK. The clinical and biological roles of transforming growth factor beta in colon cancer stem cells: A systematic review. Eur J Cell Biol. 2018;97(1):15-22.

67. Kunath T, Saba-El-Leil MK, Almousailleakh M, Wray J, Meloche S, Smith A FGF stimulation of the Erk1/2 signalling cascade triggers transition of pluripotent embryonic stem cells from self-renewal to lineage commitment. Development. 2007;134(16):2895-902.

68. Xu C, Inokuma MS, Denham J, Golds K, Kundu P, Gold JD, et al. Feeder-free growth of undifferentiated human embryonic stem cells. Nat Biotechnol. 2001;19(10):971-4.

69. di Martino E, Tomlinson DC, Knowles MA. A Decade of FGF Receptor Research in Bladder Cancer: Past, Present, and Future Challenges. Adv Urol. 2012;2012:429213.

70. Ponti D, Costa A, Zaffaroni N, Pratesi G, Petrangolini G, Coradini D, et al. Isolation and in vitro propagation of tumorigenic breast cancer cells with stem/progenitor cell properties. Cancer Res. 2005;65(13):5506-11.

71. Dirks PB. Brain tumor stem cells: bringing order to the chaos of brain cancer. J Clin Oncol. 2008;26(17):2916-24.

72. Otte J, Dizdar L, Behrens B, Goering W, Knoefel WT, Wruck W, et al. FGF Signalling in the Self-Renewal of Colon Cancer Organoids. Sci Rep. 2019;9(1):17365.

73. Fulda S. The PI3K/Akt/mTOR pathway as therapeutic target in neuroblastoma. Curr Cancer Drug Targets. 2009;9(6):729-37.

74. Mabuchi S, Kuroda H, Takahashi R, Sasano T. The PI3K/AKT/mTOR pathway as a therapeutic target in ovarian cancer. Gynecol Oncol. 2015;137(1):173-9.

75. Shahcheraghi SH, Tchokonte-Nana V, Lotfi M, Lotfi M, Ghorbani A, Sadeghnia HR. Wnt/beta-catenin and PI3K/Akt/mtor Signaling Pathways in Glioblastoma: Two main targets for drug design: A Review. Curr Pharm Des. 2020. Published online ahead of print, https://doi.org/10.2174/1381612826666200131100630.

76. Jurkowska RZ, Jurkowski TP, Jeltsch A. Structure and function of mammalian DNA methyltransferases. Chembiochem Eur J Chem Biol. 2011;12(2):206-22.

77. Koh KP, Yabuuchi A, Rao S, Huang Y, Cunniff K, Nardone J, et al. Tet1 and Tet2 regulate 5 -hydroxymethylcytosine production and cell lineage specification in mouse embryonic stem cells. Cell Stem Cell. 2011;8(2):200-13.

78. Boyer LA, Plath K, Zeitlinger J, Brambrink T, Medeiros LA, Lee TI, et al. Polycomb complexes repress developmental regulators in murine embryonic stem cells. Nature. 2006:441(7091):349-53.

79. Taneja G, Maity S, Jiang W, Moorthy B, Coarfa C, Ghose R. Transcriptomic profiling identifies novel mechanisms of transcriptional regulation of the cytochrome P450 (Cyp)3a11 gene. Sci Rep. 2019;9(1):6663.

80. Siddique HR, Saleem M. Role of BMI1, a stem cell factor, in cancer recurrence and chemoresistance: preclinical and clinical evidences. Stem Cells. 2012;30(3):372-8

81. Morita R, Hirohashi Y, Suzuki H, Takahashi A, Tamura Y, Kanaseki T, et al. DNA methyltransferase 1 is essential for initiation of the colon cancers. Exp Mol Pathol. 2013;94(2):322-9.

82. Song SJ, Poliseno L, Song MS, Ala U, Webster K, Ng C, et al. MicroRNAantagonism regulates breast cancer stemness and metastasis via TET-familydependent chromatin remodeling. Cell. 2013;154(2):311-24.

83. van Vlerken LE, Kiefer CM, Morehouse C, Li Y, Groves C, Wilson SD, et al. $\mathrm{EZH} 2$ is required for breast and pancreatic cancer stem cell maintenance and can be used as a functional cancer stem cell reporter. Stem Cells Transl Med. 2013;2(1):43-52.

84. Suva ML, Riggi N, Janiszewska M, Radovanovic I, Provero P, Stehle JC, et al. EZH2 is essential for glioblastoma cancer stem cell maintenance. Cancer Res. 2009;69(24):9211-8.

85. Richter GH, Plehm S, Fasan A, Rossler S, Unland R, Bennani-Baiti IM, et al. $\mathrm{EZH} 2$ is a mediator of EWS/FLI1 driven tumor growth and metastasis blocking endothelial and neuro-ectodermal differentiation. Proc Natl Acad Sci U S A. 2009;106(13):5324-9.

86. Jin J, Lv X, Chen L, Zhang W, Li J, Wang Q, et al. Bmi-1 plays a critical role in protection from renal tubulointerstitial injury by maintaining redox balance. Aging Cell. 2014;13(5):797-809.

87. Nor C, Zhang Z, Warner KA, Bernardi L, Visioli F, Helman Jl, et al. Cisplatin induces Bmi-1 and enhances the stem cell fraction in head and neck cancer. Neoplasia. 2014;16(2):137-46.

88. Kreso A, van Galen P, Pedley NM, Lima-Fernandes E, Frelin C, Davis T, et al. Self-renewal as a therapeutic target in human colorectal cancer. Nat Med. 2014;20(1):29-36.

89. Jares $\mathrm{P}$, Campo E. Advances in the understanding of mantle cell lymphoma. Br J Haematol. 2008;142(2):149-65.
90. Hiopoulos D, Lindahl-Allen M, Polytarchou C, Hirsch HA, Tsichlis PN, Struhl K. Loss of miR-200 inhibition of Suz12 leads to polycomb-mediated repression required for the formation and maintenance of cancer stem cells. Mol Cell. 2010;39(5):761-72.

91. Heddleston JM, Wu Q, Rivera M, Minhas S, Lathia JD, Sloan AE, et al. Hypoxia-induced mixed-lineage leukemia 1 regulates glioma stem cell tumorigenic potential. Cell Death Differ. 2012;19(3):428-39.

92. Choi DS, Blanco E, Kim YS, Rodriguez AA, Zhao H, Huang TH, et al. Chloroquine eliminates cancer stem cells through deregulation of Jak2 and DNMT1. Stem Cells. 2014;32(9):2309-23.

93. Ferrone CK, Blydt-Hansen M, Rauh MJ. Age-Associated TET2 Mutations: Common Drivers of Myeloid Dysfunction, Cancer and Cardiovascular Disease. Int J Mol Sci. 2020;21(2):626.

94. Yu X, Jiang X, Li H, Guo L, Jiang W, Lu SH. miR-203 inhibits the proliferation and self-renewal of esophageal cancer stem-like cells by suppressing stem renewal factor Bmi-1. Stem Cells Dev. 2014;23(6):576-85.

95. Yu D, Liu Y, Yang J, Jin C, Zhao X, Cheng J, et al. Clinical implications of BMI-1 in cancer stem cells of laryngeal carcinoma. Cell Biochem Biophys. 2015;71(1):261-9.

96. Chang B, Li S, He Q, Liu Z, Zhao L, Zhao T, et al. Deregulation of Bmi-1 is associated with enhanced migration, invasion and poor prognosis in salivary adenoid cystic carcinoma. Biochim Biophys Acta. 2014;1840(12): 3285-91.

97. Benoit YD, Witherspoon MS, Laursen KB, Guezguez A, Beausejour M, Beaulieu JF, et al. Pharmacological inhibition of polycomb repressive complex-2 activity induces apoptosis in human colon cancer stem cells. Exp Cell Res. 2013;319(10):1463-70.

98. Viswanathan SR, Daley GQ, Gregory RI. Selective blockade of microRNA processing by Lin28. Science. 2008;320(5872):97-100

99. Newman MA, Thomson JM, Hammond SM. Lin-28 interaction with the Let-7 precursor loop mediates regulated microRNA processing. Rna. 2008;14(8): 1539-49.

100. Yu L, Xu Y, Qu H, Yu Y, Li W, Zhao Y, et al. Decrease of MiR-31 induced by TNF-alpha inhibitor activates SATB2/RUNX2 pathway and promotes osteogenic differentiation in ethanol-induced osteonecrosis. J Cell Physiol. 2019:234(4):4314-26.

101. Xu N, Papagiannakopoulos T, Pan G, Thomson JA, Kosik KS. MicroRNA-145 regulates OCT4, SOX2, and KLF4 and represses pluripotency in human embryonic stem cells. Cell. 2009;137(4):647-58.

102. Wellner U, Schubert J, Burk UC, Schmalhofer O, Zhu F, Sonntag A, et al. The EMT-activator ZEB1 promotes tumorigenicity by repressing stemnessinhibiting microRNAs. Nat Cell Biol. 2009;11(12):1487-95.

103. Wang $Y, X u Z$, Jiang J, Xu C, Kang J, Xiao L, et al. Endogenous miRNA sponge lincRNA-RoR regulates Oct4, Nanog, and Sox2 in human embryonic stem cell self-renewal. Dev Cell. 2013;25(1):69-80.

104. Yu F, Yao H, Zhu P, Zhang X, Pan Q, Gong C, et al. let-7 regulates self renewal and tumorigenicity of breast cancer cells. Cell. 2007;131(6):1109-23.

105. Garg M. Epithelial, mesenchymal and hybrid epithelial/mesenchymal phenotypes and their clinical relevance in cancer metastasis. Expert Rev Mol Med. 2017;19:e3

106. Li Y, Guessous F, Zhang Y, Dipierro C, Kefas B, Johnson E, et al. MicroRNA34 a inhibits glioblastoma growth by targeting multiple oncogenes. Cancer Res. 2009;69(19):7569-76.

107. Ji Q, Hao X, Zhang M, Tang W, Yang M, Li L, et al. MicroRNA miR-34 inhibits human pancreatic cancer tumor-initiating cells. PLoS One. 2009:4(8):e6816.

108. Bu P, Chen KY, Chen JH, Wang L, Walters J, Shin YJ, et al. A microRNA miR34a-regulated bimodal switch targets Notch in colon cancer stem cells. Cell Stem Cell. 2013;12(5):602-15.

109. Yang YP, Chien Y, Chiou GY, Cherng JY, Wang ML, Lo WL, et al. Inhibition of cancer stem cell-like properties and reduced chemoradioresistance of glioblastoma using microRNA145 with cationic polyurethane-short branch PEI. Biomaterials. 2012;33(5):1462-76.

110. Geng YJ, Xie SL, Li Q, Ma J, Wang GY. Large intervening non-coding RNA HOTAIR is associated with hepatocellular carcinoma progression. J Int Med Res. 2011;39(6):2119-28.

111. Liu C, Kelnar K, Liu B, Chen X, Calhoun-Davis T, Li H, et al. The microRNA miR-34a inhibits prostate cancer stem cells and metastasis by directly repressing CD44. Nat Med. 2011;17(2):211-5.

112. Ji Q, Hao X, Meng Y, Zhang M, Desano J, Fan D, et al. Restoration of tumor suppressor miR-34 inhibits human p53-mutant gastric cancer tumorspheres. BMC Cancer. 2008;8:266 
113. Alison MR, Poulsom R, Forbes S, Wright NA. An introduction to stem cells. J Pathol. 2002;197(4):419-23.

114. Gerson SL, Reese J, Kenyon J. DNA repair in stem cell maintenance and conversion to cancer stem cells. Ernst Schering Foundation Symp Proc. 2006;5:231-44.

115. Easwaran H, Tsai HC, Baylin SB. Cancer epigenetics: tumor heterogeneity, plasticity of stem-like states, and drug resistance. Mol Cell. 2014;54(5):716-27.

116. Bao S, Wu Q, McLendon RE, Hao Y, Shi Q, Hjelmeland AB, et al. Glioma stem cells promote radioresistance by preferential activation of the DNA damage response. Nature. 2006;444(7120):756-60.

117. Olcina M, Lecane PS, Hammond EM. Targeting hypoxic cells through the DNA damage response. Clin Cancer Res. 2010;16(23):5624-9.

118. Jones DL, Wagers AJ. No place like home: anatomy and function of the stem cell niche. Nature reviews. Mol Cell Biol. 2008;9(1):11-21.

119. Borovski T, De Sousa EMF, Vermeulen L, Medema JP. Cancer stem cell niche: the place to be. Cancer Res. 2011;71(3):634-9.

120. Plaks V, Kong N, Werb Z. The cancer stem cell niche: how essential is the niche in regulating stemness of tumor cells? Cell Stem Cell. 2015;16(3):225-38.

121. Tetteh PW, Farin HF, Clevers H. Plasticity within stem cell hierarchies in mammalian epithelia. Trends Cell Biol. 2015;25(2):100-8.

122. Chaffer CL, Brueckmann I, Scheel C, Kaestli AJ, Wiggins PA, Rodrigues LO, et al. Normal and neoplastic nonstem cells can spontaneously convert to a stem-like state. Proc Natl Acad Sci U S A. 2011;108(19):7950-5.

123. Nichols J, Zevnik B, Anastassiadis K, Niwa H, Klewe-Nebenius D, Chambers I, et al. Formation of pluripotent stem cells in the mammalian embryo depends on the POU transcription factor Oct4. Cell. 1998;95(3):379-91.

124. Niwa H, Miyazaki J, Smith AG. Quantitative expression of Oct-3/4 defines differentiation, dedifferentiation or self-renewal of ES cells. Nat Genet. 2000; 24(4):372-6.

125. Shimozaki K, Nakashima K, Niwa H, Taga T. Involvement of Oct3/4 in the enhancement of neuronal differentiation of ES cells in neurogenesisinducing cultures. Development. 2003;130(11):2505-12.

126. Xu K, Zhu Z, Zeng F. Expression and significance of Oct4 in bladder cancer. Journal of Huazhong University of Science and Technology. Medical sciences $=$ Hua zhong ke ji da xue xue bao. Yi xue Ying De wen ban = Huazhong keji daxue xuebao. Yixue Yingdewen ban. 2007;27(6):675-7.

127. Hatefi N, Nouraee N, Parvin M, Ziaee SA, Mowla SJ. Evaluating the expression of oct4 as a prognostic tumor marker in bladder cancer. Iran J Basic Med Sci. 2012;15(6):1154-61.

128. de Resende MF, Chinen LT, Vieira S, Jampietro J, da Fonseca FP, Vassallo J, et al. Prognostication of OCT4 isoform expression in prostate cancer. Tumour Biol. 2013;34(5):2665-73.

129. Rodini CO, Suzuki DE, Saba-Silva N, Cappellano A, de Souza JE, Cavalheiro S, et al. Expression analysis of stem cell-related genes reveal OCT4 as a predictor of poor clinical outcome in medulloblastoma. J Neurooncol. 2012; 106(1):71-9.

130. Li C, Yan Y, Ji W, Bao L, Qian H, Chen L, et al. OCT4 positively regulates Survivin expression to promote cancer cell proliferation and leads to poor prognosis in esophageal squamous cell carcinoma. PLoS One. 2012;7(11): e49693.

131. Avilion AA, Nicolis SK, Pevny LH, Perez L, Vivian N, Lovell-Badge R. Multipotent cell lineages in early mouse development depend on SOX2 function. Genes Dev. 2003:17(1):126-40.

132. Masui S, Nakatake Y, Toyooka Y, Shimosato D, Yagi R, Takahashi K, et al. Pluripotency governed by Sox 2 via regulation of Oct $3 / 4$ expression in mouse embryonic stem cells. Nat Cell Biol. 2007;9(6):625-35.

133. Boer B, Kopp J, Mallanna S, Desler M, Chakravarthy H, Wilder PJ, et al. Elevating the levels of Sox2 in embryonal carcinoma cells and embryonic stem cells inhibits the expression of Sox2:Oct-3/4 target genes. Nucleic Acids Res. 2007;35(6):1773-86.

134. Kopp JL, Ormsbee BD, Desler M, Rizzino A. Small increases in the level of Sox2 trigger the differentiation of mouse embryonic stem cells. Stem Cells. 2008;26(4):903-11.

135. Ying J, Shi C, Li CS, Hu LP, Zhang WD. Expression and significance of SOX2 in non-small cell lung carcinoma. Oncol Lett. 2016;12(5):3195-8.

136. Wang Q, He W, Lu C, Wang Z, Wang J, Giercksky KE, et al. Oct3/4 and Sox2 are significantly associated with an unfavorable clinical outcome in human esophageal squamous cell carcinoma. Anticancer Res. 2009; 29(4):1233-41.

137. Forghanifard MM, Ardalan Khales S, Javdani-Mallak A, Rad A, Farshchian M, Abbaszadegan MR. Stemness state regulators SALL4 and SOX2 are involved in progression and invasiveness of esophageal squamous cell carcinoma. Med Oncol. 2014;31(4):922.

138. Li XL, Eishi Y, Bai YQ, Sakai H, Akiyama Y, Tani M, et al. Expression of the SRY-related HMG box protein SOX2 in human gastric carcinoma. Int J Oncol. 2004;24(2):257-63.

139. Zhang $X, Y u H$, Yang $Y$, Zhu R, Bai J, Peng Z, et al. SOX2 in gastric carcinoma, but not Hath1, is related to patients' clinicopathological features and prognosis. J Gastrointestinal Surg. 2010;14(8):1220-6.

140. Matsuoka J, Yashiro M, Sakurai K, Kubo N, Tanaka H, Muguruma K, et al. Role of the stemness factors sox 2 , oct $3 / 4$, and nanog in gastric carcinoma. J Surg Res. 2012;174(1):130-5

141. Li X, Wang J, Xu Z, Ahmad A, Li E, Wang Y, et al. Expression of Sox2 and Oct4 and their clinical significance in human non-small-cell lung cancer. Int J Mol Sci. 2012;13(6):7663-75.

142. Chen $Y$, Huang $Y$, Huang $Y$, Chen J, Wang S, Zhou J. The prognostic value of SOX2 expression in non-small cell lung cancer: a meta-analysis. PLoS One. 2013:8(8):e71140.

143. Inoue $Y$, Matsuura $S$, Kurabe $N$, Kahyo T, Mori H, Kawase A, et al. Clinicopathological and Survival Analysis of Japanese Patients with Resected Non-Small-Cell Lung Cancer Harboring NKX2-1, SETDB1, MET, HER2, SOX2, FGFR1, or PIK3CA Gene Amplification. J Thoracic Oncol. 2015;10(11):1590600.

144. Leis O, Eguiara A, Lopez-Arribillaga E, Alberdi MJ, Hernandez-Garcia S, Elorriaga $\mathrm{K}$, et al. Sox2 expression in breast tumours and activation in breast cancer stem cells. Oncogene. 2012;31(11):1354-65.

145. Gillis AJ, Stoop H, Biermann K, van Gurp RJ, Swartzman E, Cribbes S, et al. Expression and interdependencies of pluripotency factors LIN28, OCT3/4, NANOG and SOX2 in human testicular germ cells and tumours of the testis. Int J Androl. 2011;34(4 Pt 2):e160-74.

146. Pham DL, Scheble V, Bareiss P, Fischer A, Beschorner C, Adam A, et al. SOX2 expression and prognostic significance in ovarian carcinoma. Int J Gynecol Pathol. 2013:32(4):358-67.

147. Ivanova N, Dobrin R, Lu R, Kotenko I, Levorse J, DeCoste C, et al. Dissecting self-renewal in stem cells with RNA interference. Nature. 2006:442(7102): 533-8.

148. Ghaleb AM, Nandan MO, Chanchevalap S, Dalton WB, Hisamuddin IM, Yang W. Kruppel-like factors 4 and 5 : the yin and yang regulators of cellular proliferation. Cell Res. 2005;15(2):92-6.

149. Bourillot PY, Savatier P. Kruppel-like transcription factors and control of pluripotency. BMC Biol. 2010;8:125.

150. Leng Z, Tao K, Xia Q, Tan J, Yue Z, Chen J, et al. Kruppel-like factor 4 acts as an oncogene in colon cancer stem cell-enriched spheroid cells. PLoS One. 2013;8(2):e56082.

151. Nakatake Y, Fukui N, Iwamatsu Y, Masui S, Takahashi K, Yagi R, et al. Klf4 cooperates with Oct3/4 and Sox2 to activate the Lefty1 core promoter in embryonic stem cells. Mol Cell Biol. 2006;26(20):7772-82.

152. Jiang J, Chan YS, Loh YH, Cai J, Tong GQ, Lim CA, et al. A core Klf circuitry regulates self-renewal of embryonic stem cells. Nat Cell Biol. 2008;10(3):35360.

153. Patel NV, Ghaleb AM, Nandan MO, Yang WW. Expression of the tumor suppressor Kruppel-like factor 4 as a prognostic predictor for colon cancer. Cancer Epidemiol Biomarkers Prev. 2010;19(10):2631-8.

154. Tai SK, Yang MH, Chang SY, Chang YC, Li WY, Tsai TL, et al. Persistent Kruppel-like factor 4 expression predicts progression and poor prognosis of head and neck squamous cell carcinoma. Cancer Sci. 2011; 102(4):895-902.

155. Pandya AY, Talley LI, Frost AR, Fitzgerald TJ, Trivedi V, Chakravarthy M, et al. Nuclear localization of KLF4 is associated with an aggressive phenotype in early-stage breast cancer. Clin Cancer Res. 2004;10(8):2709-19.

156. Liu Z, Yang H, Luo W, Jiang Q, Mai C, Chen Y, et al. Loss of cytoplasmic KLF4 expression is correlated with the progression and poor prognosis of nasopharyngeal carcinoma. Histopathology. 2013;63(3):362-70.

157. Chen CJ, Hsu LS, Lin SH, Chen MK, Wang HK, Hsu JD, et al. Loss of nuclear expression of Kruppel-like factor 4 is associated with poor prognosis in patients with oral cancer. Hum Pathol. 2012;43(7):1119-25.

158. Mitsui K, Tokuzawa Y, Itoh H, Segawa K, Murakami M, Takahashi K, et al. The homeoprotein Nanog is required for maintenance of pluripotency in mouse epiblast and ES cells. Cell. 2003:113(5):631-42.

159. Chambers I, Colby D, Robertson M, Nichols J, Lee S, Tweedie S, et al. Functional expression cloning of Nanog, a pluripotency sustaining factor in embryonic stem cells. Cell. 2003;113(5):643-55. 
160. Silva J, Nichols J, Theunissen TW, Guo G, van Oosten AL, Barrandon O, et al. Nanog is the gateway to the pluripotent ground state. Cell. 2009;138(4): $722-37$

161. Kuroda T, Tada M, Kubota H, Kimura H, Hatano SY, Suemori H, et al. Octamer and Sox elements are required for transcriptional cis regulation of Nanog gene expression. Mol Cell Biol. 2005;25(6):2475-85.

162. Chen $X, X u H$, Yuan P, Fang F, Huss M, Vega VB, et al. Integration of external signaling pathways with the core transcriptional network in embryonic stem cells. Cell. 2008;133(6):1106-17.

163. Lerchl A. Letter on 'The effect of pulsed 900-MHz GSM mobile phone radiation on the acrosome reaction, head morphometry and zona binding of human spermatozoa' by Falzone et al. (Int J Androl 34: 20-26, 2011). Int J Androl. 2012;35(1):103 author reply 04

164. Meng HM, Zheng P, Wang XY, Liu C, Sui HM, Wu SJ, et al. Over-expression of Nanog predicts tumor progression and poor prognosis in colorectal cancer. Cancer Biol Ther. 2010;9(4):295-302.

165. Chen H, Laba JM, Boldt RG, Goodman CD, Palma DA, Senan S, et al. Stereotactic Ablative Radiation Therapy Versus Surgery in Early Lung Cancer: A Meta-analysis of Propensity Score Studies. Int J Radiat Oncol Biol Phys. 2018;101(1):186-94.

166. Li XQ, Yang XL, Zhang G, Wu SP, Deng XB, Xiao SJ, et al. Nuclear betacatenin accumulation is associated with increased expression of Nanog protein and predicts poor prognosis of non-small cell lung cancer. J Trans Med. 2013;11:114

167. Lee M, Nam EJ, Kim SW, Kim S, Kim JH, Kim YT. Prognostic impact of the cancer stem cell-related marker NANOG in ovarian serous carcinoma. Int J Gynecol Cancer. 2012;22(9):1489-96.

168. Sun C, Sun L, Jiang K, Gao DM, Kang XN, Wang C, et al. NANOG promotes liver cancer cell invasion by inducing epithelial-mesenchymal transition through NODAL/SMAD3 signaling pathway. Int J Biochem Cell Biol. 2013; 45(6):1099-108.

169. Cole MD, Henriksson M. 25 years of the c-Myc oncogene. Semin Cancer Biol. 2006;16(4):241.

170. Laurenti E, Wilson A, Trumpp A. Myc's other life: stem cells and beyond. Curr Opin Cell Biol. 2009;21(6):844-54.

171. Meyer N, Kim SS, Penn LZ. The Oscar-worthy role of Myc in apoptosis. Semin Cancer Biol. 2006;16(4):275-87.

172. Cartwright P, McLean C, Sheppard A, Rivett D, Jones K, Dalton S. LIF/STAT3 controls ES cell self-renewal and pluripotency by a Myc-dependent mechanism. Development. 2005;132(5):885-96

173. Chappell J, Sun Y, Singh A, Dalton S. MYC/MAX control ERK signaling and pluripotency by regulation of dual-specificity phosphatases 2 and 7. Genes Dev. 2013;27(7):725-33.

174. Kim J, Woo AJ, Chu J, Snow JW, Fujiwara Y, Kim CG, et al. A Myc network accounts for similarities between embryonic stem and cancer cell transcription programs. Cell. 2010;143(2):313-24.

175. Dang CV. MYC on the path to cancer. Cell. 2012;149(1):22-35.

176. Wang Y, Wu MC, Sham JS, Zhang W, Wu WQ, Guan XY. Prognostic significance of c-myc and AIB1 amplification in hepatocellular carcinoma. A broad survey using high-throughput tissue microarray. Cancer. 2002;95(11): 2346-52.

177. Riou G, Barrois M, Le MG, George M, Le Doussal V, Haie C. C-myc protooncogene expression and prognosis in early carcinoma of the uterine cervix. Lancet. 1987;1(8536):761-3.

178. Colombo N, Carinelli S, Colombo A, Marini C, Rollo D, Sessa C, et al. Cervical cancer: ESMO Clinical Practice Guidelines for diagnosis, treatment and follow-up. Ann Oncol. 2012;23(Suppl 7):vii27-32.

179. Poli V, Fagnocchi L, Fasciani A, Cherubini A, Mazzoleni S, Ferrillo S, et al. MYC-driven epigenetic reprogramming favors the onset of tumorigenesis by inducing a stem cell-like state. Nat Commun. 2018;9(1):1024

180. Krizhanovsky V, Lowe SW. Stem cells: The promises and perils of p53. Nature. 2009:460(7259):1085-6.

181. Spike BT, Wahl GM. p53, Stem Cells, and Reprogramming: Tumor Suppression beyond Guarding the Genome. Genes Cancer. 2011;2(4): 404-19.

182. Jiang $H$, Xu Z, Zhong $P$, Ren $Y$, Liang G, Schilling HA, et al. Cell cycle and p53 gate the direct conversion of human fibroblasts to dopaminergic neurons. Nat Commun. 2015:6:10100.

183. Aronheim A, Zandi E, Hennemann H, Elledge SJ, Karin M. Isolation of an AP1 repressor by a novel method for detecting protein-protein interactions. Mol Cell Biol. 1997;17(6):3094-102.
184. Jin C, Li H, Murata T, Sun K, Horikoshi M, Chiu R, et al. JDP2, a repressor of $A P-1$, recruits a histone deacetylase 3 complex to inhibit the retinoic acidinduced differentiation of F9 cells. Mol Cell Biol. 2002;22(13):4815-26.

185. Tsai MH, Wuputra K, Lin YC, Lin CS, Yokoyama KK. Multiple functions of the histone chaperone Jun dimerization protein 2. Gene. 2016;590(2):193-200.

186. Pan J, Nakade K, Huang YC, Zhu ZW, Masuzaki S, Hasegawa H, et al. Suppression of cell-cycle progression by Jun dimerization protein-2 (JDP2) involves downregulation of cyclin-A2. Oncogene. 2011;30:3648.

187. Weidenfeld-Baranboim K, Bitton-Worms K, Aronheim A. TRE-dependent transcription activation by JDP2-CHOP10 association. Nucleic Acids Res. 2008:36(11):3608-19.

188. Saito S, Lin YC, Tsai MH, Lin CS, Murayama Y, Sato R, et al. Emerging roles of hypoxia-inducible factors and reactive oxygen species in cancer and pluripotent stem cells. Kaohsiung J Med Sci. 2015;31(6):279-86.

189. Tanigawa S, Lee CH, Lin CS, Ku CC, Hasegawa H, Qin S, et al. Jun dimerization protein 2 is a critical component of the Nrf2/MafK complex regulating the response to ROS homeostasis. Cell Death Dis. 2013:4:e921.

190. Esteban MA, Wang T, Qin B, Yang J, Qin D, Cai J, et al. Vitamin C enhances the generation of mouse and human induced pluripotent stem cells. Cell Stem Cell. 2010;6(1):71-9.

191. Kielman MF, Rindapaa M, Gaspar C, van Poppel N, Breukel C, van Leeuwen $\mathrm{S}$, et al. Apc modulates embryonic stem-cell differentiation by controlling the dosage of beta-catenin signaling. Nat Genet. 2002;32(4):594-605.

192. Marson A, Foreman R, Chevalier B, Bilodeau S, Kahn M, Young RA, et al. Wnt signaling promotes reprogramming of somatic cells to pluripotency. Cell Stem Cell. 2008;3(2):132-5.

193. Ogawa K, Nishinakamura R, Iwamatsu Y, Shimosato D, Niwa H. Synergistic action of Wnt and LIF in maintaining pluripotency of mouse ES cells. Biochem Biophys Res Commun. 2006;343(1):159-66.

194. Takao Y, Yokota T, Koide H. Beta-catenin up-regulates Nanog expression through interaction with Oct-3/4 in embryonic stem cells. Biochem Biophys Res Commun. 2007:353(3):699-705.

195. Wu DC, Wang SSW, Liu CJ, Wuputra K, Kato K, Lee YL, et al. Reprogramming Antagonizes the Oncogenicity of HOXA13-Long Noncoding RNA HOTTIP Axis in Gastric Cancer Cells. Stem Cells. 2017;35(10):2115-28.

196. Weigmann A, Corbeil D, Hellwig A, Huttner WB. Prominin, a novel microvillispecific polytopic membrane protein of the apical surface of epithelial cells, is targeted to plasmalemmal protrusions of non-epithelial cells. Proc Natl Acad Sci U S A. 1997;94(23):12425-30

197. Glumac PM, LeBeau AM. The role of CD133 in cancer: a concise review. Clin Transl Med. 2018;7(1):18.

198. Singh SK, Clarke ID, Terasaki M, Bonn VE, Hawkins C, Squire J, et al. Identification of a cancer stem cell in human brain tumors. Cancer Res. 2003;63(18):5821-8.

199. Vaiopoulos AG, Kostakis ID, Koutsilieris M, Papavassiliou AG. Colorectal cancer stem cells. Stem Cells. 2012;30(3):363-71.

200. O'Brien CA, Pollett A, Gallinger S, Dick JE. A human colon cancer cell capable of initiating tumour growth in immunodeficient mice. Nature. 2007; 445(7123):106-10

201. Eramo A, Lotti F, Sette G, Pilozzi E, Biffoni M, Di Virgilio A, et al. Identification and expansion of the tumorigenic lung cancer stem cell population. Cell Death Differ. 2008;15(3):504-14

202. Lin SH, Liu T, Ming X, Tang Z, Fu L, Schmitt-Kopplin P, et al. Regulatory role of hexosamine biosynthetic pathway on hepatic cancer stem cell marker CD133 under low glucose conditions. Sci Rep. 2016:6:21184.

203. Collins AT, Berry PA, Hyde C, Stower MJ, Maitland NJ. Prospective identification of tumorigenic prostate cancer stem cells. Cancer Res. 2005; 65(23):10946-51.

204. Chen H, Luo Z, Dong L, Tan Y, Yang J, Feng G, et al. CD133/prominin-1mediated autophagy and glucose uptake beneficial for hepatoma cell survival. PLoS One. 2013;8(2):e56878.

205. Du L, Wang H, He L, Zhang J, Ni B, Wang X, et al. CD44 is of functional importance for colorectal cancer stem cells. Clin Cancer Res. 2008;14(21): 6751-60.

206. Shmelkov SV, Butler JM, Hooper AT, Hormigo A, Kushner J, Milde T, et al. CD133 expression is not restricted to stem cells, and both CD133+ and CD133- metastatic colon cancer cells initiate tumors. J Clin Invest. 2008; 118(6):2111-20.

207. Misra S, Hascall VC, Berger FG, Markwald RR, Ghatak S. Hyaluronan, CD44, and cyclooxygenase-2 in colon cancer. Connect Tissue Res. 2008:49(3): 219-24. 
208. Ghatak S, Misra S, Toole BP. Hyaluronan constitutively regulates ErbB2 phosphorylation and signaling complex formation in carcinoma cells. J Biol Chem. 2005;280(10):8875-83.

209. Misra S, Hascall VC, Markwald RR, Ghatak S. Interactions between Hyaluronan and Its Receptors (CD44, RHAMM) Regulate the Activities of Inflammation and Cancer. Front Immunol. 2015;6:201.

210. Al-Hajj M, Wicha MS, Benito-Hernandez A, Morrison SJ, Clarke MF. Prospective identification of tumorigenic breast cancer cells. Proc Natl Acad Sci U S A. 2003;100(7):3983-8.

211. Dontu G, Abdallah WM, Foley JM, Jackson KW, Clarke MF, Kawamura MJ, et al. In vitro propagation and transcriptional profiling of human mammary stem/progenitor cells. Genes Dev. 2003;17(10):1253-70.

212. Patrawala L, Calhoun T, Schneider-Broussard R, Li H, Bhatia B, Tang S, et al. Highly purified CD44+ prostate cancer cells from xenograft human tumors are enriched in tumorigenic and metastatic progenitor cells. Oncogene. 2006;25(12):1696-708.

213. Hurt EM, Kawasaki BT, Klarmann GJ, Thomas SB, Farrar WL. CD44+ CD24(-) prostate cells are early cancer progenitor/stem cells that provide a model for patients with poor prognosis. Br J Cancer. 2008; 98(4):756-65.

214. Dalerba P, Dylla SJ, Park IK, Liu R, Wang X, Cho RW, et al. Phenotypic characterization of human colorectal cancer stem cells. Proc Natl Acad Sci U S A. 2007;104(24):10158-63.

215. Todaro M, Gaggianesi M, Catalano V, Benfante A, lovino F, Biffoni M, et al. CD44v6 is a marker of constitutive and reprogrammed cancer stem cells driving colon cancer metastasis. Cell Stem Cell. 2014;14(3):342-56.

216. Li C, Heidt DG, Dalerba P, Burant CF, Zhang L, Adsay V, et al. Identification of pancreatic cancer stem cells. Cancer Res. 2007:67(3):1030-7.

217. Prince ME, Sivanandan R, Kaczorowski A, Wolf GT, Kaplan MJ, Dalerba P, et al. Identification of a subpopulation of cells with cancer stem cell properties in head and neck squamous cell carcinoma. Proc Natl Acad Sci U S A. 2007;104(3):973-8

218. Hang D, Dong HC, Ning T, Dong B, Hou DL, Xu WG. Prognostic value of the stem cell markers CD133 and ABCG2 expression in esophageal squamous cell carcinoma. Dis Esophagus. 2012;25(7):638-44.

219. Ding $X W, W u J H$, Jiang $C P$. ABCG2: a potential marker of stem cells and novel target in stem cell and cancer therapy. Life Sci. 2010;86(1718):631-7.

220. Zhang G, Wang Z, Luo W, Jiao H, Wu J, Jiang C. Expression of Potential Cancer Stem Cell Marker ABCG2 is Associated with Malignant Behaviors of Hepatocellular Carcinoma. Gastroenterol Res Pract. 2013:2013:782581.

221. Haraguchi N, Ishii H, Mimori K, Tanaka F, Ohkuma M, Kim HM, et al. CD13 is a therapeutic target in human liver cancer stem cells. J Clin Invest. 2010; 120(9):3326-39.

222. Hashida H, Takabayashi A, Kanai M, Adachi M, Kondo K, Kohno N, et al. Aminopeptidase $\mathrm{N}$ is involved in cell motility and angiogenesis: its clinical significance in human colon cancer. Gastroenterology. 2002;122(2):376-86.

223. Schreiber CL, Smith BD. Molecular Imaging of Aminopeptidase N in Cancer and Angiogenesis. Contrast Media Mol Imaging. 2018;2018:5315172.

224. Al-Kharusi MR, Smartt HJ, Greenhough A, Collard TJ, Emery ED, Williams AC, et al. LGR5 promotes survival in human colorectal adenoma cells and is upregulated by PGE2: implications for targeting adenoma stem cells with NSAIDs. Carcinogenesis. 2013;34(5):1150-7.

225. Lebensohn AM, Rohatgi R. R-spondins can potentiate WNT signaling without LGRs. eLife. 2018;7:e33126.

226. Zhou X, Geng L, Wang D, Yi H, Talmon G, Wang J. R-Spondin1/LGR5 Activates TGFbeta Signaling and Suppresses Colon Cancer Metastasis. Cancer Res. 2017;77(23):6589-602.

227. Walker $F$, Zhang HH, Odorizzi A, Burgess AW. LGR5 is a negative regulator of tumourigenicity, antagonizes Wnt signalling and regulates cell adhesion in colorectal cancer cell lines. PLoS One. 2011;6(7):e22733.

228. Haegebarth A, Clevers H. Wnt signaling, lgr5, and stem cells in the intestine and skin. Am J Pathol. 2009;174(3):715-21.

229. Morgan RG, Mortensson E, Williams AC. Targeting LGR5 in Colorectal Cancer: therapeutic gold or too plastic? Br J Cancer. 2018;118(11):1410-8.

230. Anderson R, Schaible K, Heasman J, Wylie C. Expression of the homophilic adhesion molecule, Ep-CAM, in the mammalian germ line. J Reprod Fertil. 1999:116(2):379-84.

231. Huang L, Yang Y, Yang F, Liu S, Zhu Z, Lei Z, et al. Functions of EpCAM in physiological processes and diseases (Review). Int J Mol Med. 2018;42(4): $1771-85$.
232. Cochrane CR, Szczepny A, Watkins DN, Cain JE. Hedgehog Signaling in the Maintenance of Cancer Stem Cells. Cancers. 2015;7(3):1554-85.

233. Varjosalo M, Taipale J. Hedgehog: functions and mechanisms. Genes Dev. 2008;22(18):2454-72.

234. Takebe N, Miele L, Harris PJ, Jeong W, Bando H, Kahn M, et al. Targeting Notch, Hedgehog, and Wnt pathways in cancer stem cells: clinical update. Nat Rev Clin Oncol. 2015;12(8):445-64.

235. Yu X, Zou J, Ye Z, Hammond H, Chen G, Tokunaga A, et al. Notch signaling activation in human embryonic stem cells is required for embryonic, but not trophoblastic, lineage commitment. Cell Stem Cell. 2008;2(5):461-71.

236. Yuan X, Wu H, Xu H, Xiong H, Chu Q, Yu S, et al. Notch signaling: an emerging therapeutic target for cancer treatment. Cancer Lett. 2015;369(1):20-7.

237. Stine RR, Matunis EL. JAK-STAT signaling in stem cells. Adv Exp Med Biol. 2013;786:247-67.

238. Morgensztern D, McLeod HL. PI3K/Akt/mTOR pathway as a target for cancer therapy. Anticancer Drugs. 2005;16(8):797-803.

239. Slomovitz BM, Coleman RL. The PI3K/AKT/mTOR pathway as a therapeutic target in endometrial cancer. Clin Cancer Res. 2012;18(21):5856-64.

240. Dos Santos C, Recher C, Demur C, Payrastre B. The PI3K/Akt/mTOR pathway: a new therapeutic target in the treatment of acute myeloid leukemia. Bull Cancer. 2006;93(5):445-7.

241. Valkenburg KC, Graveel CR, Zylstra-Diegel CR, Zhong Z, Williams BO. Wnt/ beta-catenin Signaling in Normal and Cancer Stem Cells. Cancers. 2011;3(2): 2050-79.

242. Ashihara E, Takada T, Maekawa T. Targeting the canonical Wnt/beta-catenin pathway in hematological malignancies. Cancer Sci. 2015;106(6):665-71.

243. Gedaly R, Galuppo R, Daily MF, Shah M, Maynard E, Chen C, et al. Targeting the Wnt/beta-catenin signaling pathway in liver cancer stem cells and hepatocellular carcinoma cell lines with FH535. PLoS One. 2014;9(6):e99272

244. Yao H, Ashihara E, Maekawa T. Targeting the Wnt/beta-catenin signaling pathway in human cancers. Expert Opin Ther Targets. 2011;15(7):873-87.

245. De S, Ganesan S. Looking beyond drivers and passengers in cancer genome sequencing data. Ann Oncol. 2017;28(5):938-45.

246. Pon JR, Marra MA. Driver and passenger mutations in cancer. Annu Rev Pathol. 2015;10:25-50.

247. Gonzalez-Perez A, Mustonen V, Reva B, Ritchie GR, Creixell P, Karchin R, et al. Computational approaches to identify functional genetic variants in cancer genomes. Nat Methods. 2013;10(8):723-9.

248. Meyerson M, Gabriel S, Getz G. Advances in understanding cancer genomes through second-generation sequencing. Nat Rev Genet. 2010;11(10):685-96.

249. Watson IR, Takahashi K, Futreal PA, Chin L. Emerging patterns of somatic mutations in cancer. Nat Rev Genet. 2013;14(10):703-18.

250. Kato S, Lippman SM, Flaherty KT, Kurzrock R. The Conundrum of Genetic "Drivers" in Benign Conditions. J Natl Cancer Inst. 2016;108(8):djw036.

251. Treutlein B, Brownfield DG, Wu AR, Neff NF, Mantalas GL, Espinoza FH, et al. Reconstructing lineage hierarchies of the distal lung epithelium using single-cell RNA-seq. Nature. 2014;509(7500):371-5.

252. Halpern KB, Shenhav R, Matcovitch-Natan O, Toth B, Lemze D, Golan M, et al. Single-cell spatial reconstruction reveals global division of labour in the mammalian liver. Nature. 2017:542(7641):352-6.

253. Wang YJ, Schug J, Won KJ, Liu C, Naji A, Avrahami D, et al. Single-Cell Transcriptomics of the Human Endocrine Pancreas. Diabetes. 2016;65(10): 3028-38.

254. Muraro MJ, Dharmadhikari G, Grun D, Groen N, Dielen T, Jansen E, et al. A Single-Cell Transcriptome Atlas of the Human Pancreas. Cell Systems. 2016; 3(4):385-94 e3.

255. Barriga FM, Montagni E, Mana M, Mendez-Lago M, Hernando-Momblona X, Sevillano M, et al. Mex3a Marks a Slowly Dividing Subpopulation of Lgr5+ Intestinal Stem Cells. Cell Stem Cell. 2017;20(6):801-16 e7.

256. Johnson E, Dickerson KL, Connolly ID, Hayden GM. Single-Cell RNASequencing in Glioma. Curr Oncol Rep. 2018:20(5):42.

257. Kilpinen H, Goncalves A, Leha A, Afzal V, Alasoo K, Ashford S, et al. Common genetic variation drives molecular heterogeneity in human iPSCs. Nature. 2017;546(7658):370-5.

258. Voog J, Jones DL. Stem cells and the niche: a dynamic duo. Cell Stem Cell. 2010;6(2):103-15.

259. Hanahan D, Coussens LM. Accessories to the crime: functions of cells recruited to the tumor microenvironment. Cancer Cell. 2012;21(3):309-22.

260. Korkaya H, Liu S, Wicha MS. Breast cancer stem cells, cytokine networks, and the tumor microenvironment. J Clin Invest. 2011;121(10):3804-9. 
261. Shue YT, Lim JS, Sage J. Tumor heterogeneity in small cell lung cancer defined and investigated in pre-clinical mouse models. Transl Lung Cancer Res. 2018;7(1):21-31.

262. Fessler E, Dijkgraaf FE, De Sousa EMF, Medema JP. Cancer stem cell dynamics in tumor progression and metastasis: is the microenvironment to blame? Cancer Lett. 2013;341(1):97-104.

263. Kumano K, Arai S, Hosoi M, Taoka K, Takayama N, Otsu M, et al. Generation of induced pluripotent stem cells from primary chronic myelogenous leukemia patient samples. Blood. 2012;119(26):6234-42

264. Wang B, Miyagoe-Suzuki Y, Yada E, Ito N, Nishiyama T, Nakamura M, et al. Reprogramming efficiency and quality of induced Pluripotent Stem Cells (iPSCs) generated from muscle-derived fibroblasts of mdx mice at different ages. PLoS Currents. 2011;3:RRN1274.

265. Ben-David $U$, Benvenisty N. The tumorigenicity of human embryonic and induced pluripotent stem cells. Nat Rev Cancer. 2011;11(4):268-77.

266. Goldring CE, Duffy PA, Benvenisty N, Andrews PW, Ben-David U, Eakins R, et al. Assessing the safety of stem cell therapeutics. Cell Stem Cell. 2011;8(6): 618-28.

267. Daniel Fl, Cherubini K, Yurgel LS, de Figueiredo MA, Salum FG. The role of epigenetic transcription repression and DNA methyltransferases in cancer. Cancer. 2011;117(4):677-87.

268. McDonald OG, Li X, Saunders T, Tryggvadottir R, Mentch SJ, Warmoes MO, et al. Epigenomic reprogramming during pancreatic cancer progression links anabolic glucose metabolism to distant metastasis. Nat Genet. 2017; 49(3):367-76.

269. Roe JS, Hwang Cl, Somerville TDD, Milazzo JP, Lee EJ, Da Silva B, et al. Enhancer Reprogramming Promotes Pancreatic Cancer Metastasis. Cell. 2017;170(5):875-88 e20.

270. Kanwal R, Gupta S. Epigenetic modifications in cancer. Clin Genet. 2012; 81(4):303-11.

271. Pattani KM, Soudry E, Glazer CA, Ochs MF, Wang H, Schussel J, et al. MAGEB2 is activated by promoter demethylation in head and neck squamous cell carcinoma. PLoS One. 2012;7(9):e45534.

272. Skvortsova K, lovino N, Bogdanovic O. Functions and mechanisms of epigenetic inheritance in animals. Nature reviews. Mol Cell Biol. 2018;19(12): 774-90.

273. Sabari BR, Dall'Agnese A, Boija A, Klein IA, Coffey EL, Shrinivas K, et al. Coactivator condensation at super-enhancers links phase separation and gene control. Science. 2018;361(6400):eaar3958.

274. Guo YE, Manteiga JC, Henninger JE, Sabari BR, Dall'Agnese A, Hannett NM, et al. Pol II phosphorylation regulates a switch between transcriptional and splicing condensates. Nature. 2019;572(7770):543-8.

275. Li S, Zheng EB, Zhao L, Liu S. Nonreciprocal and Conditional Cooperativity Directs the Pioneer Activity of Pluripotency Transcription Factors. Cell Rep. 2019;28(10):2689-703 e4

276. Chatterjee A, Rodger EJ, Eccles MR. Epigenetic drivers of tumourigenesis and cancer metastasis. Semin Cancer Biol. 2018;51:149-59.

277. Jones PA. Functions of DNA methylation: islands, start sites, gene bodies and beyond. Nat Rev Genet. 2012;13(7):484-92.

278. Kondo Y, Shen L, Cheng AS, Ahmed S, Boumber Y, Charo C, et al. Gene silencing in cancer by histone $\mathrm{H} 3$ lysine 27 trimethylation independent of promoter DNA methylation. Nat Genet. 2008;40(6):741-50.

279. Funato $K$, Major T, Lewis PW, Allis CD, Tabar V. Use of human embryonic stem cells to model pediatric gliomas with H3.3K27M histone mutation. Science. 2014;346(6216):1529-33.

280. Lewis PW, Muller MM, Koletsky MS, Cordero F, Lin S, Banaszynski LA, et al. Inhibition of PRC2 activity by a gain-of-function $\mathrm{H} 3$ mutation found in pediatric glioblastoma. Science. 2013;340(6134):857-61.

281. Simon JA, Kingston RE. Occupying chromatin: Polycomb mechanisms for getting to genomic targets, stopping transcriptional traffic, and staying put. Mol Cell. 2013:49(5):808-24

282. Sze CC, Shilatifard A. MLL3/MLL4/COMPASS Family on Epigenetic Regulation of Enhancer Function and Cancer. Cold Spring Harb Perspect Med. 2016;6(11):a026427.

283. Di Croce L, Helin K. Transcriptional regulation by Polycomb group proteins. Nat Struct Mol Biol. 2013;20(10):1147-55

284. Abdouh M, Facchino S, Chatoo W, Balasingam V, Ferreira J, Bernier G. BMI1 sustains human glioblastoma multiforme stem cell renewal. J Neurosci. 2009;29(28):8884-96.

285. Clapier CR, Cairns BR. The biology of chromatin remodeling complexes. Annu Rev Biochem. 2009;78:273-304.
286. Nakayama RT, Pulice JL, Valencia AM, McBride MJ, McKenzie ZM, Gillespie MA, et al. SMARCB1 is required for widespread BAF complex-mediated activation of enhancers and bivalent promoters. Nat Genet. 2017;49(11): 1613-23.

287. Wang X, Lee RS, Alver BH, Haswell JR, Wang S, Mieczkowski J, et al. SMARCB1-mediated SWI/SNF complex function is essential for enhancer regulation. Nat Genet. 2017;49(2):289-95.

288. Mathur R, Alver BH, San Roman AK, Wilson BG, Wang X, Agoston AT, et al. ARID1A loss impairs enhancer-mediated gene regulation and drives colon cancer in mice. Nat Genet. 2017;49(2):296-302.

289. Schuettengruber B, Bourbon HM, Di Croce L, Cavalli G. Genome Regulation by Polycomb and Trithorax: 70 Years and Counting. Cell. 2017;171(1):34-57.

290. Gallo M, Coutinho FJ, Vanner RJ, Gayden T, Mack SC, Murison A, et al. MLL5 Orchestrates a Cancer Self-Renewal State by Repressing the Histone Variant H3.3 and Globally Reorganizing Chromatin. Cancer Cell. 2015;28(6):715-29.

291. Torres CM, Biran A, Burney MJ, Patel H, Henser-Brownhill T, Cohen AS, et al. The linker histone $\mathrm{H} 1.0$ generates epigenetic and functional intratumor heterogeneity. Science. 2016;353(6307):aaf1644.

292. Apostolou E, Hochedlinger K. Chromatin dynamics during cellular reprogramming. Nature. 2013;502(7472):462-71.

293. Ge Y, Fuchs E. Stretching the limits: from homeostasis to stem cell plasticity in wound healing and cancer. Nat Rev Genet. 2018;19(5):311-25.

294. Chen L, Deng H, Cui H, Fang J, Zuo Z, Deng J, et al. Inflammatory responses and inflammation-associated diseases in organs. Oncotarget. 2018;9(6): 7204-18.

295. Wiseman H, Halliwell B. Damage to DNA by reactive oxygen and nitrogen species: role in inflammatory disease and progression to cancer. Biochem J. 1996:313(Pt 1):17-29.

296. Oskarsson T, Batlle E, Massague J. Metastatic stem cells: sources, niches, and vital pathways. Cell Stem Cell. 2014;14(3):306-21.

297. Nair N, Calle AS, Zahra MH, Prieto-Vila M, Oo AKK, Hurley L, et al. A cancer stem cell model as the point of origin of cancer-associated fibroblasts in tumor microenvironment. Sci Rep. 2017;7(1):6838.

298. Kleinewietfeld M, Manzel A, Titze J, Kvakan H, Yosef N, Linker RA, et al. Sodium chloride drives autoimmune disease by the induction of pathogenic TH17 cells. Nature. 2013;496(7446):518-22.

299. Broz ML, Binnewies M, Boldajipour B, Nelson AE, Pollack JL, Erle DJ, et al. Dissecting the tumor myeloid compartment reveals rare activating antigenpresenting cells critical for T cell immunity. Cancer Cell. 2014;26(5):638-52.

300. Cabarcas SM, Mathews LA, Farrar WL. The cancer stem cell niche--there goes the neighborhood? Int J Cancer. 2011;129(10):2315-27.

301. Gilbertson RJ, Rich JN. Making a tumour's bed: glioblastoma stem cells and the vascular niche. Nat Rev Cancer. 2007:7(10):733-6.

302. Dalerba P, Cho RW, Clarke MF. Cancer stem cells: models and concepts. Annu Rev Med. 2007:58:267-84.

303. Iida T, Iwanami A, Sanosaka T, Kohyama J, Miyoshi H, Nagoshi N, et al. Whole-Genome DNA Methylation Analyses Revealed Epigenetic Instability in Tumorigenic Human iPS Cell-Derived Neural Stem/Progenitor Cells. Stem Cells. 2017:35(5):1316-27.

304. Nebbioso A, Tambaro FP, Dell'Aversana C, Altucci L. Cancer epigenetics: Moving forward. PLoS Genet. 2018;14(6):e1007362.

305. Nguyen LV, Vanner R, Dirks P, Eaves CJ. Cancer stem cells: an evolving concept. Nat Rev Cancer. 2012;12(2):133-43.

306. Saito S, Lin YC, Nakamura Y, Eckner R, Wuputra K, Kuo KK, et al. Potential application of cell reprogramming techniques for cancer research. Cell Mol Life Sci. 2019;76(1):45-65.

307. Kawamura T, Suzuki J, Wang Y, Menendez S, Morera LB, Raya A, et al. Linking the p53 tumour suppressor pathway to somatic cell reprogramming. Nature. 2009;460(7259):1140-4.

308. Marion RM, Strati K, Li H, Murga M, Blanco R, Ortega S, et al. A p53mediated DNA damage response limits reprogramming to ensure iPS cell genomic integrity. Nature. 2009;460(7259):1149-53.

309. Belikov AV. The number of key carcinogenic events can be predicted from cancer incidence. Sci Rep. 2017:7(1):12170.

310. Bos JL. ras oncogenes in human cancer: a review. Cancer Res. 1989;49(17): 4682-9.

311. Chang EH, Furth ME, Scolnick EM, Lowy DR. Tumorigenic transformation of mammalian cells induced by a normal human gene homologous to the oncogene of Harvey murine sarcoma virus. Nature. 1982;297(5866):479-83.

312. Gidekel S, Pizov G, Bergman Y, Pikarsky E. Oct-3/4 is a dose-dependent oncogenic fate determinant. Cancer Cell. 2003;4(5):361-70. 
313. Sanada Y, Yoshida K, Ohara M, Oeda M, Konishi K, Tsutani Y. Histopathologic evaluation of stepwise progression of pancreatic carcinoma with immunohistochemical analysis of gastric epithelial transcription factor SOX2: comparison of expression patterns between invasive components and cancerous or nonneoplastic intraductal components. Pancreas. 2006;32(2): $164-70$.

314. Bae KM, Su Z, Frye C, McClellan S, Allan RW, Andrejewski JT, et al. Expression of pluripotent stem cell reprogramming factors by prostate tumor initiating cells. J Urol. 2010;183(5):2045-53.

315. Atlasi Y, Mowla SJ, Ziaee SA, Bahrami AR. OCT-4, an embryonic stem cell marker, is highly expressed in bladder cancer. Int J Cancer. 2007;120(7): 1598-602.

316. Gustafson WC, Weiss WA. Myc proteins as therapeutic targets. Oncogene. 2010;29(9):1249-59.

317. Stadtfeld M, Hochedlinger K. Induced pluripotency: history, mechanisms, and applications. Genes Dev. 2010;24(20):2239-63.

318. Sarig R, Rivlin N, Brosh R, Bornstein C, Kamer I, Ezra O, et al. Mutant p53 facilitates somatic cell reprogramming and augments the malignant potential of reprogrammed cells. J Exp Med. 2010;207(10):2127-40.

319. Zheng H, Ying H, Yan H, Kimmelman AC, Hiller DJ, Chen AJ, et al. p53 and Pten control neural and glioma stem/progenitor cell renewal and differentiation. Nature. 2008;455(7216):1129-33.

320. Hanoun M, Maryanovich M, Arnal-Estape A, Frenette PS. Neural regulation of hematopoiesis, inflammation, and cancer. Neuron. 2015; 86(2):360-73.

321. Jobling P, Pundavela J, Oliveira SM, Roselli S, Walker MM, Hondermarck H. Nerve-Cancer Cell Cross-talk: A Novel Promoter of Tumor Progression. Cancer Res. 2015;75(9):1777-81.

322. Zhang Z, Lei $A$, Xu L, Chen L, Chen Y, Zhang $X$, et al. Similarity in generegulatory networks suggests that cancer cells share characteristics of embryonic neural cells. J Biol Chem. 2017;292(31):12842-59.

323. Tang C, Lee AS, Volkmer JP, Sahoo D, Nag D, Mosley AR, et al. An antibody against SSEA-5 glycan on human pluripotent stem cells enables removal of teratoma-forming cells. Nat Biotechnol. 2011;29(9):829-34.

324. Tohyama S, Hattori F, Sano M, Hishiki T, Nagahata Y, Matsuura T, et al. Distinct metabolic flow enables large-scale purification of mouse and human pluripotent stem cell-derived cardiomyocytes. Cell Stem Cell. 2013; 12(1):127-37.

325. Ben-David U, Gan QF, Golan-Lev T, Arora P, Yanuka O, Oren YS, et al. Selective elimination of human pluripotent stem cells by an oleate synthesis inhibitor discovered in a high-throughput screen. Cell Stem Cell. 2013;12(2): 167-79.

326. Dabir DV, Hasson SA, Setoguchi K, Johnson ME, Wongkongkathep P, Douglas $C J$, et al. A small molecule inhibitor of redox-regulated protein translocation into mitochondria. Dev Cell. 2013;25(1):81-92.

327. Lee MO, Moon SH, Jeong HC, Yi JY, Lee TH, Shim SH, et al. Inhibition of pluripotent stem cell-derived teratoma formation by small molecules. Proc Natl Acad Sci U S A. 2013;110(35):E3281-90.

328. Blum B, Bar-Nur O, Golan-Lev T, Benvenisty N. The anti-apoptotic gene survivin contributes to teratoma formation by human embryonic stem cells. Nat Biotechnol. 2009;27(3):281-7.

329. Menendez S, Camus S, Herreria A, Paramonov I, Morera LB, Collado M, et al. Increased dosage of tumor suppressors limits the tumorigenicity of iPS cells without affecting their pluripotency. Aging Cell. 2012;11(1):41-50.

330. Schuldiner M, Itskovitz-Eldor J, Benvenisty N. Selective ablation of human embryonic stem cells expressing a "suicide" gene. Stem Cells. 2003;21(3): 257-65.

331. Tan HL, Fong WJ, Lee EH, Yap M, Choo A. mAb 84, a cytotoxic antibody that kills undifferentiated human embryonic stem cells via oncosis. Stem Cells. 2009;27(8):1792-801.

332. Choo AB, Tan HL, Ang SN, Fong WJ, Chin A, Lo J, et al. Selection against undifferentiated human embryonic stem cells by a cytotoxic antibody recognizing podocalyxin-like protein-1. Stem Cells. 2008;26(6):1454-63.

333. Ben-David U, Nudel N, Benvenisty N. Immunologic and chemical targeting of the tight-junction protein Claudin-6 eliminates tumorigenic human pluripotent stem cells. Nat Commun. 2013:4:1992.

334. Fong CY, Peh GS, Gauthaman K, Bongso A. Separation of SSEA-4 and TRA-160 labelled undifferentiated human embryonic stem cells from a heterogeneous cell population using magnetic-activated cell sorting (MACS) and fluorescence-activated cell sorting (FACS). Stem Cell Rev Rep. 2009;5(1): $72-80$.
335. Ben-David U, Benvenisty N. Chemical ablation of tumor-initiating human pluripotent stem cells. Nat Protoc. 2014;9(3):729-40.

336. Bieberich E, Hu B, Silva J, MacKinnon S, Yu RK, Fillmore H, et al. Synthesis and characterization of novel ceramide analogs for induction of apoptosis in human cancer cells. Cancer Lett. 2002;181(1):55-64.

337. Bieberich E, MacKinnon S, Silva J, Noggle S, Condie BG. Regulation of cell death in mitotic neural progenitor cells by asymmetric distribution of prostate apoptosis response 4 (PAR-4) and simultaneous elevation of endogenous ceramide. J Cell Biol. 2003;162(3):469-79.

338. Leushacke M, Tan SH, Wong A, Swathi Y, Hajamohideen A, Tan LT, et al. Lgr5-expressing chief cells drive epithelial regeneration and cancer in the oxyntic stomach. Nat Cell Biol. 2017;19(7):774-86.

339. Lin YT, Wang CK, Yang SC, Hsu SC, Lin H, Chang FP, et al. Elimination of undifferentiated human embryonic stem cells by cardiac glycosides. Sci Rep. 2017;7(1):5289.

340. Richards M, Phoon CW, Goh GT, Seng EK, Guo XM, Tan CM, et al. A new class of pluripotent stem cell cytotoxic small molecules. PLoS One. 2014; 9(3):e85039.

341. Wang YC, Nakagawa M, Garitaonandia I, Slavin I, Altun G, Lacharite RM, et al. Specific lectin biomarkers for isolation of human pluripotent stem cells identified through array-based glycomic analysis. Cell Res. 2011;21(11):155163 .

342. Terstegge S, Winter F, Rath BH, Laufenberg I, Schwarz C, Leinhaas A, et al. Laser-assisted photoablation of human pluripotent stem cells from differentiating cultures. Stem Cell Rev Rep. 2010;6(2):260-9.

343. Rong Z, Fu X, Wang M, Xu Y. A scalable approach to prevent teratoma formation of human embryonic stem cells. J Biol Chem. 2012;287(39): 32338-45.

344. Kobayashi Y, Okada Y, Itakura G, Iwai H, Nishimura S, Yasuda A, et al. Preevaluated safe human iPSC-derived neural stem cells promote functional recovery after spinal cord injury in common marmoset without tumorigenicity. PLoS One. 2012;7(12):e52787.

345. Wyles SP, Yamada S, Oommen S, Maleszewski JJ, Beraldi R, MartinezFernandez A, et al. Inhibition of DNA topoisomerase II selectively reduces the threat of tumorigenicity following induced pluripotent stem cell-based myocardial therapy. Stem Cells Dev. 2014;23(19):2274-82.

346. Huskey NE, Guo T, Evason KJ, Momcilovic O, Pardo D, Creasman KJ, et al. CDK1 inhibition targets the p53-NOXA-MCL1 axis, selectively kills embryonic stem cells, and prevents teratoma formation. Stem Cell Rep. 2015;4(3):374-89.

347. Bedel A, Beliveau F, Lamrissi-Garcia I, Rousseau B, Moranvillier I, Rucheton B, et al. Preventing Pluripotent Cell Teratoma in Regenerative Medicine Applied to Hematology Disorders. Stem Cells Transl Med. 2017;6(2):382-93.

348. Itakura G, Kawabata S, Ando M, Nishiyama Y, Sugai K, Ozaki M, et al. FailSafe System against Potential Tumorigenicity after Transplantation of iPSC Derivatives. Stem Cell Rep. 2017:8(3):673-84.

349. Nori S, Okada Y, Yasuda A, Tsuji O, Takahashi Y, Kobayashi Y, et al. Grafted human-induced pluripotent stem-cell-derived neurospheres promote motor functional recovery after spinal cord injury in mice. Proc Natl Acad Sci U S A. 2011;108(40):16825-30.

350. Khoshchehreh R, Totonchi M, Carlos Ramirez J, Torres R, Baharvand H, Aicher $\mathrm{A}$, et al. Epigenetic reprogramming of primary pancreatic cancer cells counteracts their in vivo tumourigenicity. Oncogene. 2019;38(34):6226-39.

351. Pepin ME, Ha CM, Crossman DK, Litovsky SH, Varambally S, Barchue JP, et al. Genome-wide DNA methylation encodes cardiac transcriptional reprogramming in human ischemic heart failure. Lab Invest J Technical Methods Pathol. 2019;99(3):371-86.

352. Liu D, Zhang XX, Li MC, Cao CH, Wan DY, Xi BX, et al. C/EBPbeta enhances platinum resistance of ovarian cancer cells by reprogramming H3K79 methylation. Nat Commun. 2018;9(1):1739.

353. Yagi M, Yamanaka S, Yamada Y. Epigenetic foundations of pluripotent stem cells that recapitulate in vivo pluripotency. Lab Invest J Technical Methods Pathol. 2017:97(10):1133-41.

354. Prassas I, Diamandis EP. Translational researchers beware! Unreliable commercial immunoassays (ELISAs) can jeopardize your research. Clin Chem Lab Med. 2014;52(6):765-6.

355. Knoepfler PS. Deconstructing stem cell tumorigenicity: a roadmap to safe regenerative medicine. Stem Cells. 2009;27(5):1050-6.

356. Pinkham K, Park DJ, Hashemiaghdam A, Kirov AB, Adam I, Rosiak K, et al. Stearoyl CoA Desaturase Is Essential for Regulation of Endoplasmic Reticulum Homeostasis and Tumor Growth in Glioblastoma Cancer Stem Cells. Stem Cell Rep. 2019;12(4):712-27. 
357. Tsuji O, Miura K, Okada Y, Fujiyoshi K, Mukaino M, Nagoshi N, et al. Therapeutic potential of appropriately evaluated safe-induced pluripotent stem cells for spinal cord injury. Proc Natl Acad Sci U S A. 2010;107(28): 12704-9.

358. Mitsui K, Ide K, Takahashi T, Kosai Kl. Viral Vector-Based Innovative Approaches to Directly Abolishing Tumorigenic Pluripotent Stem Cells for Safer Regenerative Medicine. Molecular therapy. Methods Clin Dev. 2017;5 $51-8$.

359. Ushiku T, Shinozaki-Ushiku A, Maeda D, Morita S, Fukayama M. Distinct expression pattern of claudin-6, a primitive phenotypic tight junction molecule, in germ cell tumours and visceral carcinomas. Histopathology. 2012;61(6):1043-56.

360. Simonson OE, Domogatskaya A, Volchkov P, Rodin S. The safety of human pluripotent stem cells in clinical treatment. Ann Med. 2015;47(5):370-80.

361. Avraham S, Korin B, Aviram S, Shechter D, Shaked Y, Aronheim A. ATF3 and JDP2 deficiency in cancer associated fibroblasts promotes tumor growth via SDF-1 transcription. Oncogene. 2019;38(20):3812-23.

362. Bitton-Worms K, Pikarsky E, Aronheim A. The AP-1 repressor protein, JDP2, potentiates hepatocellular carcinoma in mice. Mol Cancer. 2010;9:54.

363. van der Weyden L, Rust AG, Mclntyre RE, Robles-Espinoza CD, del Castillo VHM, Strogantsev R, et al. Jdp2 downregulates Trp53 transcription to promote leukaemogenesis in the context of Trp53 heterozygosity. Oncogene. 2013;32(3):397-402.

364. Huang YC, Hasegawa H, Wang SW, Ku CC, Lin YC, Chiou SS, et al. Jun dimerization protein 2 controls senescence and differentiation via regulating histone modification. J Biomed Biotechnol. 2011;2011:569034.

365. Wang SS, Wuputra K, Liu CJ, Lin YC, Chen YT, Chai CY, et al. Oncogenic function of the homeobox A13-long noncoding RNA HOTTIP-insulin growth factor-binding protein 3 axis in human gastric cancer. Oncotarget. 2016; 7(24):36049-64.

366. Vethe H, Ghila L, Berle M, Hoareau L, Haaland OA, Scholz H, et al. The Effect of Wnt Pathway Modulators on Human iPSC-Derived Pancreatic Beta Cell Maturation. Front Endocrinol. 2019;10:293.

367. Cao L, Wu G, Zhu J, Tan Z, Shi D, Wu X, et al. Genotoxic stress-triggered beta-catenin/JDP2/PRMT5 complex facilitates reestablishing glutathione homeostasis. Nat Commun. 2019;10(1):3761.

368. Wang B, Wu L, Li D, Liu Y, Guo J, Li C, et al. Induction of Pluripotent Stem Cells from Mouse Embryonic Fibroblasts by Jdp2-Jhdm1b-Mkk6-Glis1Nanog-Essrb-Sall4. Cell Rep. 2019;27(12):3473-85 e5.

369. Pasha Z, Haider $H$, Ashraf M. Efficient non-viral reprogramming of myoblasts to stemness with a single small molecule to generate cardiac progenitor cells. PLoS One. 2011;6(8):e23667.

370. Ichida JK, Blanchard J, Lam K, Son EY, Chung JE, Egli D, et al. A smallmolecule inhibitor of tgf-Beta signaling replaces sox2 in reprogramming by inducing nanog. Cell Stem Cell. 2009;5(5):491-503.

371. Li W, Wei W, Zhu S, Zhu J, Shi Y, Lin T, et al. Generation of rat and human induced pluripotent stem cells by combining genetic reprogramming and chemical inhibitors. Cell Stem Cell. 2009;4(1):16-9.

372. Szablowska-Gadomska I, Sypecka J, Zayat V, Podobinska M, Pastwinska A Pienkowska-Grela B, et al. Treatment with small molecules is an important milestone towards the induction of pluripotency in neural stem cells derived from human cord blood. Acta Neurobiol Exp. 2012;72(4):337-50.

373. Cimmino L, Dolgalev I, Wang Y, Yoshimi A, Martin GH, Wang J, et al. Restoration of TET2 Function Blocks Aberrant Self-Renewal and Leukemia Progression. Cell. 2017;170(6):1079-95 e20.

374. Cimmino L, Neel BG, Aifantis I. Vitamin C in Stem Cell Reprogramming and Cancer. Trends Cell Biol. 2018;28(9):698-708.

375. Gustafson CB, Yang C, Dickson KM, Shao H, Van Booven D, Harbour JW, et al. Epigenetic reprogramming of melanoma cells by vitamin $C$ treatment. Clin Epigenetics. 2015;7:51

376. Wang T, Chen K, Zeng X, Yang J, Wu Y, Shi X, et al. The histone demethylases Jhdm1a/1b enhance somatic cell reprogramming in a vitamin-C-dependent manner. Cell Stem Cell. 2011;9(6):575-87.

377. Lopez-Otin C, Blasco MA, Partridge L, Serrano M, Kroemer G. The hallmarks of aging. Cell. 2013;153(6):1194-217.

378. Mosteiro L, Pantoja C, Alcazar N, Marion R M, Chondronasiou D, Rovira M, et al. Tissue damage and senescence provide critical signals for cellular reprogramming in vivo. Science. 2016;354(6315):aaf4445.

379. Ocampo A, Reddy P, Martinez-Redondo P, Platero-Luengo A, Hatanaka F, Hishida T, et al. In Vivo Amelioration of Age-Associated Hallmarks by Partial Reprogramming. Cell. 2016;167(7):1719-33 e12.
380. Chiche A, Le Roux I, von Joest M, Sakai H, Aguin SB, Cazin C, et al. InjuryInduced Senescence Enables In Vivo Reprogramming in Skeletal Muscle. Cell Stem Cell. 2017;20(3):407-14 e4.

381. Ritschka B, Storer M, Mas A, Heinzmann F, Ortells MC, Morton JP, et al. The senescence-associated secretory phenotype induces cellular plasticity and tissue regeneration. Genes Dev. 2017;31(2):172-83.

382. Broxmeyer HE. Will iPS cells enhance therapeutic applicability of cord blood cells and banking? Cell Stem Cell. 2010;6(1):21-4.

383. Diaz-Prado S, Muinos-Lopez E, Hermida-Gomez T, Cicione C, Rendal-Vazquez ME, Fuentes-Boquete I, et al. Human amniotic membrane as an alternative source of stem cells for regenerative medicine. Differentiation; Res Biol Divers. 2011;81(3):162-71.

384. Wang JP, Ouyang GF. Phenotypic identification and differentiation potential analysis of two kinds of human amniotic cells. Zhongguo Shi Yan Xue Ye Xue Za Zhi. 2012;20(1):146-53.

385. Wolfrum K, Wang Y, Prigione A, Sperling K, Lehrach $H$, Adjaye J. The LARGE principle of cellular reprogramming: lost, acquired and retained gene expression in foreskin and amniotic fluid-derived human iPS cells. PLoS One. 2010;5(10):e13703.

386. Jozefczuk J, Drews K, Adjaye J. Preparation of mouse embryonic fibroblast cells suitable for culturing human embryonic and induced pluripotent stem cells. J Visualized Exper. 2012:64:3854.

387. Nagai K, Ishii H, Miyoshi N, Hoshino H, Saito T, Sato T, et al. Long-term culture following ES-like gene-induced reprogramming elicits an aggressive phenotype in mutated cholangiocellular carcinoma cells. Biochem Biophys Res Commun. 2010;395(2):258-63.

388. Shrinivas K, Sabari BR, Coffey EL, Klein IA, Boija A, Zamudio AV, et al. Enhancer Features that Drive Formation of Transcriptional Condensates. Mol Cell. 2019;75(3):549-61 e7.

389. Ooi WF, Xing M, Xu C, Yao X, Ramlee MK, Lim MC, et al. Epigenomic profiling of primary gastric adenocarcinoma reveals super-enhancer heterogeneity. Nat Commun. 2016;7:12983.

390. Xiong L, Wu F, Wu Q, Xu L, Cheung OK, Kang W, et al. Aberrant enhancer hypomethylation contributes to hepatic carcinogenesis through global transcriptional reprogramming. Nat Commun. 2019;10(1):335.

391. Fant CB, Taatjes DJ. Regulatory functions of the Mediator kinases CDK8 and CDK19. Transcription. 2019;10(2):76-90.

392. Chanda S, Ang CE, Lee QY, Ghebrial M, Haag D, Shibuya Y, et al. Direct Reprogramming of Human Neurons Identifies MARCKSL1 as a Pathogenic Mediator of Valproic Acid-Induced Teratogenicity. Cell Stem Cell. 2019;25(1): 103-19 e6.

393. Chan SH, Tang Y, Miao L, Darwich-Codore H, Vejnar CE, Beaudoin JD, et al. Brd4 and P300 Confer Transcriptional Competency during Zygotic Genome Activation. Dev Cell. 2019:49(6):867-81 e8.

394. Smith RC, Tabar V. Constructing and Deconstructing Cancers using Human Pluripotent Stem Cells and Organoids. Cell Stem Cell. 2019;24(1):12-24.

395. Bar S, Schachter M, Eldar-Geva T, Benvenisty N. Large-Scale Analysis of Loss of Imprinting in Human Pluripotent Stem Cells. Cell Rep. 2017;19(5):957-68.

396. Kim KY, Tanaka Y, Su J, Cakir B, Xiang Y, Patterson B, et al. Uhrf1 regulates active transcriptional marks at bivalent domains in pluripotent stem cells through Setd1a. Nat Commun. 2018;9(1):2583.

397. Weinberg DN, Papillon-Cavanagh S, Chen H, Yue Y, Chen X, Rajagopalan KN, et al. The histone mark H3K36me2 recruits DNMT3A and shapes the intergenic DNA methylation landscape. Nature. 2019:573(7773):281-6.

398. Baumann V, Wiesbeck M, Breunig CT, Braun JM, Koferle A, Ninkovic J, et al. Targeted removal of epigenetic barriers during transcriptional reprogramming. Nat Commun. 2019;10(1):2119.

399. Tran KA, Pietrzak SJ, Zaidan NZ, Siahpirani AF, McCalla SG, Zhou AS, et al. Defining Reprogramming Checkpoints from Single-Cell Analyses of Induced Pluripotency. Cell Rep. 2019;27(6):1726-41 e5.

400. Hadjimichael C, Chanoumidou K, Papadopoulou N, Arampatzi P, Papamatheakis J, Kretsovali A. Common stemness regulators of embryonic and cancer stem cells. World J Stem Cells. 2015;7(9):1150-84.

\section{Publisher's Note}

Springer Nature remains neutral with regard to jurisdictional claims in published maps and institutional affiliations. 